\title{
The relevance of carbon dioxide metabolism in Streptococcus thermophilus
}

\section{Correspondence \\ Diego Mora \\ diego.mora@unimi.it}

Received 2 October 2008

Revised 5 February 2009

Accepted 9 February 2009

\author{
Stefania Arioli, ${ }^{1}$ Paola Roncada, ${ }^{2}$ Anna Maria Salzano, ${ }^{3}$ Francesca Deriu, ${ }^{4}$ \\ Silvia Corona, ${ }^{5}$ Simone Guglielmetti, ${ }^{1}$ Luigi Bonizzi, ${ }^{4}$ Andrea Scaloni ${ }^{3}$ \\ and Diego Mora ${ }^{1}$
${ }^{1}$ Department of Food Science and Microbiology, Milan, Italy
${ }^{2}$ Istituto Sperimentale Italiano Lazzaro Spallanzani, sezione di Proteomica, Facoltà di Medicina Veterinaria, Milan, Italy
${ }^{3}$ Proteomics and Mass Spectrometry Laboratory, ISPAAM, National Research Council, Naples, Italy
${ }^{4}$ Department of Veterinary Pathology, Hygiene and Public Health, University of Milan, Milan, Italy
${ }^{5}$ IRCCS Policlinico San Matteo, Pavia, Italy

\begin{abstract}
Streptococcus thermophilus is a major component of dairy starter cultures used for the manufacture of yoghurt and cheese. In this study, the $\mathrm{CO}_{2}$ metabolism of $S$. thermophilus DSM $20617^{\top}$, grown in either a $\mathrm{N}_{2}$ atmosphere or an enriched $\mathrm{CO}_{2}$ atmosphere, was analysed using both genetic and proteomic approaches. Growth experiments performed in a chemically defined medium revealed that $\mathrm{CO}_{2}$ depletion resulted in bacterial arginine, aspartate and uracil auxotrophy. Moreover, $\mathrm{CO}_{2}$ depletion governed a significant change in cell morphology, and a high reduction in biomass production. A comparative proteomic analysis revealed that cells of $S$. thermophilus showed a different degree of energy status depending on the $\mathrm{CO}_{2}$ availability. In agreement with proteomic data, cells grown under $\mathrm{N}_{2}$ showed a significantly higher milk acidification rate compared with those grown in an enriched $\mathrm{CO}_{2}$ atmosphere. Experiments carried out on $S$. thermophilus wild-type and its derivative mutant, which was inactivated in the phosphoenolpyruvate carboxylase and carbamoyl-phosphate synthase activities responsible for fixing $\mathrm{CO}_{2}$ to organic molecules, suggested that the anaplerotic reactions governed by these enzymes have a central role in bacterial metabolism. Our results reveal the capnophilic nature of this micro-organism, underlining the essential role of $\mathrm{CO}_{2}$ in $S$. thermophilus physiology, and suggesting potential applications in dairy fermentation processes.
\end{abstract}

\section{INTRODUCTION}

Streptococcus thermophilus is a food micro-organism that is widely used in several milk fermentation processes. $S$. thermophilus is a Gram-positive lactic acid bacterium characterized by an anaerobic metabolism based on glycolysis and homolactic fermentation. The main role of $S$. thermophilus in dairy fermentations is the rapid conversion of lactose into lactate, and also the production of other compounds that contribute to food flavour and texture. Its capacity to ferment milk is strictly related to the ability of $S$. thermophilus to take up lactose from milk, and

Abbreviations: CpS, carbamoyl-phosphate synthetase; $\mathrm{HPr}(\mathrm{His}-\mathrm{P})$, histidine phosphorylated $\mathrm{HPr}$; $\mathrm{HPr}(\mathrm{Ser}-\mathrm{P})$, serine phosphorylated $\mathrm{HPr}$; $\mu$ LC-ESI-IT-MS-MS, micro liquid chromatography coupled with electrospray ionization ion trap tandem mass spectrometry; pl, isoelectric point; $\mathrm{PpC}$, phosphoenolpyruvate carboxylase.

The GenBank/EMBL/DDBJ accession number for the sequence determined in this work is AM983544. to catabolize its glucose moiety. Despite the anaerobic nature of this species, the role of $\mathrm{CO}_{2}$ on the overall metabolism of $S$. thermophilus has been investigated rarely. While a $\mathrm{CO}_{2}$-enriched atmosphere is used effectively in foodstuff preservation against bacterial spoilage, a growthstimulating effect of $\mathrm{CO}_{2}$ has been reported for a limited number of lactic acid bacterial species. Detailed studies are available for Lactobacillus plantarum and Lactococcus lactis only (Wang et al., 1998, 2000; Nicoloff et al., 2000, 2005; Arsène-Ploetze et al., 2006). The high atmospheric concentration of $\mathrm{CO}_{2}$ could have several effects on cellular physiology because it alters membrane properties, probably modifies the intracellular $\mathrm{pH}$, and interferes with carboxylation reactions. In lactic acid bacteria, and in almost all organisms, $\mathrm{CO}_{2}$ is used as a substrate for several carboxylation reactions, such as anaplerotic reactions, and amino acid and pyrimidine biosynthesis pathways. Regarding $S$. thermophilus, data available on $\mathrm{CO}_{2}$ metabolism are related to the ability of this bacterium to fix 
bicarbonate (Louaileche et al., 1993, 1996). These studies have demonstrated that $\mathrm{CO}_{2}$ and sodium bicarbonate stimulate growth and exert a marked influence on the metabolic activities of $S$. thermophilus. In analyses of the bacterial genome of two strains (Bolotin et al., 2004; Hols et al., 2005), there has been observation of two main anaplerotic pathways that are governed by enzymic activities able to fix $\mathrm{CO}_{2}$ to organic molecules. These pathways are involved in amino acid and pyrimidine synthesis, and are governed by phosphoenolpyruvate carboxylase (PpC) and carbamoyl-phosphate synthase $(\mathrm{CpS})$, which catalyse the fixation of $\mathrm{CO}_{2}$ to phosphoenolpyruvate and glutamine, respectively (Fig. 1). Recently, the $\mathrm{CO}_{2}$ metabolism of $S$. thermophilus has been investigated by evaluating the phenotype of a $\mathrm{PpC}^{-}$mutant (Arioli et al., 2007). That work demonstrated that the fixation of $\mathrm{CO}_{2}$ by $\mathrm{PpC}$ activity is fundamental for the biosynthesis of aspartic acid, and for the growth of $S$. thermophilus in milk (Arioli et al., 2007). That study also reported that the availability of aspartic acid modulates the level of urea amidohydrolase activity, underlining the existence of a link between $\mathrm{CO}_{2}$ and $\mathrm{N}_{2}$ metabolism in this species.

In the current work, the $\mathrm{CO}_{2}$ metabolism of $S$. thermophilus DSM20617 $7^{\mathrm{T}}$ was investigated by taking advantage of our previous experience in proteomic analysis of this bacterium (Arena et al., 2006; Salzano et al., 2007). To emphasize the effect of this gas on bacterial metabolism, $S$. thermophilus cells were grown on solid media under an enriched $\mathrm{CO}_{2}$ atmosphere or a $\mathrm{N}_{2}$ atmosphere, and comparatively evaluated. A differential analysis was also performed between the wild-type and a mutant that was obtained by inactivating the two enzymes involved in $\mathrm{CO}_{2}$ fixation to phosphoenolpyruvate and glutamine. Our results underline the central role of $\mathrm{CO}_{2}$ in the overall metabolism of $S$. thermophilus, and provide additional information on the physiology of this industrially important lactic acid bacterium.

\section{METHODS}

Bacterial strains, growth conditions and reagents. Wild-type $\mathrm{PpC}^{+} \mathrm{CpS}^{+}$S. thermophilus DSM 20617 ${ }^{\mathrm{T}}$, its $\mathrm{PpC}^{-}$derivative $\mathrm{A} 18(\Delta p p c)$ (Arioli et al., 2007), and the $\mathrm{PpC}^{-} \mathrm{CpS}^{-}$double mutant A19 $(\Delta p p c \Delta c a r B)$, were maintained in M17 broth (Difco Laboratories) at $37^{\circ} \mathrm{C}$. Plasmid-containing $S$. thermophilus strains were maintained in M17 broth (10 g lactose $\left.1^{-1}\right)$ supplemented with $5 \mu$ g erythromycin $\mathrm{ml}^{-1}$, at $28^{\circ} \mathrm{C}$, while strains containing the $\mathrm{pG}^{+}$host9-derived vector integrated into the chromosome were maintained in the M17 broth supplemented with $2 \mu \mathrm{g}$ erythromycin $\mathrm{ml}^{-1}$, at $42{ }^{\circ} \mathrm{C}$. Escherichia coli strains were routinely maintained in Luria-Bertani broth at $37{ }^{\circ} \mathrm{C}$ with aeration; the medium was supplemented with $10 \mu \mathrm{g}$ kanamycin $\mathrm{ml}^{-1}$ and, when necessary, with $200 \mu \mathrm{g}$ erythromycin $\mathrm{ml}^{-1}$. The auxotrophy for aspartic acid, arginine and uracil of S. thermophilus wild-type, $\mathrm{A} 18(\Delta p p c)$ and $\mathrm{A} 19(\Delta p p c \Delta c a r B)$ was evaluated in a chemically defined medium (CDM) containing lactose $\left(10 \mathrm{~g} \mathrm{l}^{-1}\right)$; this medium was derived from that described by Reiter \& Oram (1962), and modified as described by Arioli et al. (2007). A mixture containing lactose, salts and vitamins was prepared at a concentration that was $2 \times$ the concentration in CDM. After adjusting the pH to 7 using $\mathrm{NaOH}$, the mixture was autoclaved for $15 \mathrm{~min}$ at $110^{\circ} \mathrm{C}$. The amino acids were prepared as a $5 \times$ concentrated solution that was filter sterilized $(0.22 \mu \mathrm{m})$ after adjustment of its $\mathrm{pH}$ to 7 . When necessary, this medium was supplemented with $2.25 \mathrm{mM}$ L-aspartate, $0.1 \mathrm{mM}$ L-arginine, $0.2 \mathrm{mM}$ uracil, 1-5 mM urea and 1-50 $\mathrm{mM}$ sodium bicarbonate.

Cell biomass for proteomic studies was obtained by growing $S$. thermophilus on M17 agar plates. Briefly, cultures grown on solid medium were collected using sterile $\mathrm{NaCl}$ solution $\left(9 \mathrm{gl}^{-1}\right)$, harvested by centrifugation, washed twice, resuspended in sterile $\mathrm{NaCl}$ solution, and inoculated at a concentration equivalent to an $\mathrm{OD}_{595}$ of 0.7 on M17 agar containing $2 \%$ lactose, $\mathrm{pH}$ 6.8. Inoculated agar was incubated at $37{ }^{\circ} \mathrm{C}$ for $24 \mathrm{~h}$ in a $2.5 \mathrm{l}$ anaerobic jar in a $\mathrm{N}_{2}$ atmosphere, or in a $\mathrm{CO}_{2}$-enriched atmosphere $(18 \%$, v/v) obtained using one Anaerocult A sachet (Merck KGaA) in each jar. To investigate the experimental conditions under which a spontaneous release of $\mathrm{CO}_{2}$ occured during the bacterial growth, inoculated plates were incubated on M17 medium containing $1 \mathrm{mM}$ urea, under a $\mathrm{N}_{2}$ atmosphere (Mora et al., 2004, 2005).

PCR protocols and DNA sequencing. Total bacterial DNA was extracted from $100 \mu \mathrm{l}$ M17 broth culture, as previously described (Mora et al., 2004). A PCR approach for the amplification of the carB

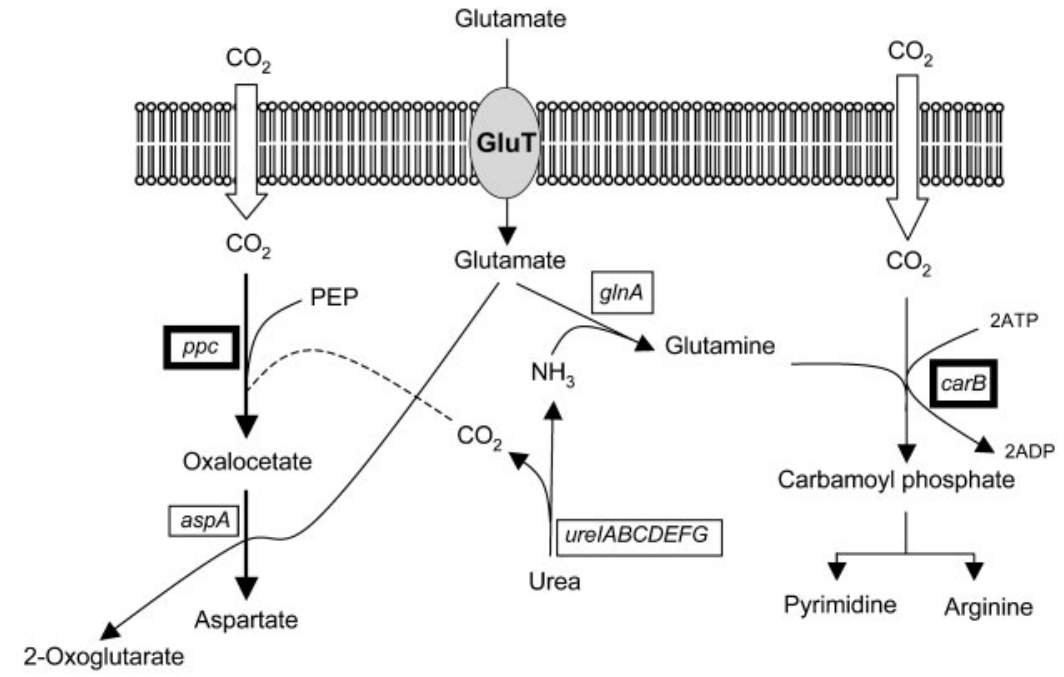

Fig. 1. Schematic representation of the anaplerotic reactions and related biosynthetic pathways involved in aspartate, arginine and pyrimidine biosynthesis, and urea metabolism, in $S$. thermophilus. $p p c$, Gene encoding phosphoenolpyruvate carboxylase; carB, gene encoding carbamoyl-phosphate synthase; asp $A$, gene encoding aspartate aminotransferase; $g \ln A$, gene encoding glutamine synthase; ureIABCDEFG, operon encoding urease; GluT, hypothetical glutamate membrane transporter. The genes $c a r B$ and $p p c$, in bold boxes, were inactivated in the mutant $A 19(\Delta p p c \Delta c a r B)$. 
gene was developed on the basis of the genome sequences of $S$. thermophilus strains LMG 18311, CNRZ1066 and LMD-9 (GenBank accession numbers CP000023, СP000024 and CP000419, respectively). The amplification of a DNA region of about $3200 \mathrm{bp}$, encompassing the whole $\operatorname{carB}$ gene, was performed as recommended by the supplier, using primers CarBF (5'-GGAAAATCGGTGAGAAAGCT-3') and CarBR (5'-CTGCTCAGCTTTTCAATCGT-3') at $0.5 \mu \mathrm{mol} 1^{-1}$, and 2 U ExTaq DNA polymerase (Takara Bio). The PCR conditions were: 35 cycles at $94{ }^{\circ} \mathrm{C}$ for $1 \mathrm{~min}, 60^{\circ} \mathrm{C}$ for $35 \mathrm{~s}$ and $72{ }^{\circ} \mathrm{C}$ for $2 \mathrm{~min}$, and a single final extension at $72{ }^{\circ} \mathrm{C}$ for $7 \mathrm{~min}$. All amplification reactions were performed in a Mastercycler (Eppendorf). The PCR product was purified (NucleoSpin Extract; Machery-Nagel), and sequenced using the CarBF and CarBR primers, followed by primer walking. The sequence reactions were analysed in a 310 automatic DNA sequencer (Applera) with fluorescent dideoxy chain terminators (Big Dye Terminator Cycle Sequencing kit version 2.0; Applera). The sequence obtained (GenBank accession no. AM983544) was analysed with ORF Finder and BLAST services at the National Center for Biotechnology Information (NCBI), and then manually aligned with the homologous carB genes of S. thermophilus LMG 18311, CNRZ1066 and LMD-9.

\section{Replacement of carB gene with a deleted version $\triangle$ carB in the mutant A18( $\mathbf{p p} \boldsymbol{p c})$. DNA manipulation of $\mathrm{pG}^{+}$host9 vector and derivatives was carried out in E. coli VE7108 (Biswas et al., 1993; Mora et al., 2004). Plasmid isolation was performed using a Nucleospin plasmid kit (Machery-Nagel), according to the manufacturer's instructions.}

Strain A19 contains a deletion of $1687 \mathrm{bp}$ in the carB gene, referred to as $\triangle c a r B$. The $\Delta c a r B$ gene was obtained by PCR, as previously described (Arioli et al., 2007; Mora et al., 2004). Briefly, DNA fragments located upstream and downstream of the $1687 \mathrm{bp}$ deletion were independently amplified using CarB1-CarB2 and CarB3-CarB4 primer pairs (CarB1, 5'-CTATTATCATTGGTCAGGCT-3'; CarB2, 5' -GTTACATACCACAAGAGCAT-3'; CarB3， 5'-GCGTGATGCCGAAGACAATGCTCTTGTGGTATGTAACTCCAAGAGACTATCGCTGA-3'; CarB4, 5' -TATCAAGGGCTGTGAAGAGT- $3^{\prime}$ ). Primer CarB3 has a 37 bp $5^{\prime}$ region complementary to the $5^{\prime}$ region of the amplified product obtained using the CarB1-CarB2 primer set. To generate a new template DNA containing a deleted version of the $p p c$ gene, these two PCR fragments were diluted to a final concentration of $100 \mathrm{fmol}$, and mixed with $5 \mu \mathrm{l}$ $10 \times$ PCR buffer, $200 \mu \mathrm{M}$ each dNTP, and $1.5 \mathrm{U}$ Taq DNA polymerase in $50 \mu \mathrm{l}$ (Amersham-Pharmacia Biotech), and subjected to the following thermal protocol: denaturation at $94{ }^{\circ} \mathrm{C}$ for $2 \mathrm{~min}$, re-association at $40{ }^{\circ} \mathrm{C}$ for $5 \mathrm{~min}$, and extension at $72{ }^{\circ} \mathrm{C}$ for $10 \mathrm{~min}$. Following this step, primers CarB5 (5'-TTATTACTGCAGCTGCAGGCAAGCTTGCTTGGCTTTGA- $\left.3^{\prime}\right)$ and CarB6 (5' -TTATTACTGCAGCTGCAGAGCTGCTCCATCTTCGTCAT- $3^{\prime}$ ), carrying a PstI site at the $5^{\prime}$ end, were added to the reaction mixture to a final concentration of $0.5 \mu \mathrm{M}$, and subjected to the following amplification protocol: 40 cycles of $94{ }^{\circ} \mathrm{C}$ for $45 \mathrm{~s}, 58{ }^{\circ} \mathrm{C}$ for $35 \mathrm{~s}$ and $72{ }^{\circ} \mathrm{C}$ for $50 \mathrm{~s}$, followed by a final extension at $72{ }^{\circ} \mathrm{C}$ for $10 \mathrm{~min}$. The resulting PCR fragment $\Delta$ carB was ligated into the dephosphorylated PstI site of $\mathrm{pG}^{+}$host9, to generate pMI76. pMI76 was introduced into $S$. thermophilus $\mathrm{A} 18(\Delta p p c)$ (Arioli et al., 2007) by using a previously described protocol (Arioli et al., 2007; Mora et al., 2004). The procedure of gene replacement described by Biswas and coworkers (Biswas et al., 1993) was then applied to the carB gene. The resulting carbamoyl-phosphate-synthase-negative mutant was named $\mathrm{A} 19(\Delta p p c \Delta c a r B)$.

Growth curves and measurements. Growth curves of DSM $20167^{\mathrm{T}}$ and the A19 derivative mutant were evaluated in triplicate at $37^{\circ} \mathrm{C}$. Briefly, cells from of an overnight M17 culture were harvested by centrifugation, washed twice, suspended in sterile $\mathrm{NaCl}$ solution $(9 \mathrm{~g}$ $\left.1^{-1}\right)$, and inoculated at a concentration equivalent to an $\mathrm{OD}_{600}$ of 0.7 in CDM. Sterile $8 \mathrm{ml}$ tubes were filled with $7.8 \mathrm{ml}$ inoculated CDM, and hermetically sealed. The growth was measured spectrophotometrically at $600 \mathrm{~nm}$. The effect of gas composition on the growth level of $S$. thermophilus was evaluated by inoculating $50 \mu \mathrm{l}$ cell suspension, prepared as described above, on the surface of plates containing $5 \mathrm{ml} \mathrm{CDM}$. After incubation of $24 \mathrm{~h}$ at $37^{\circ} \mathrm{C}$, the culture grown on the plates was collected into sterile $\mathrm{NaCl}\left(9 \mathrm{~g} \mathrm{l}^{-1}\right)$, and concentrated by centrifugation to a $1 \mathrm{ml}$ final volume in $\mathrm{NaCl}$. The cell density was evaluated spectrophotometrically at $600 \mathrm{~nm}$.

Milk acidification rate, and enzymic activity measurements. For milk acidification experiments, cells were collected as described for proteomic analysis, washed in $\mathrm{NaCl}$ solution to reach a final density of $1.2\left(\mathrm{OD}_{600}\right)$, and inoculated $(5 \%, \mathrm{v} / \mathrm{v})$ in reconstituted skimmed milk (Difco Laboratories) that had been pasteurized at $80{ }^{\circ} \mathrm{C}$ for $10 \mathrm{~min}$. Acidification measurements were followed by using a standard $\mathrm{pH}$ meter for $24 \mathrm{~h}$ at $37^{\circ} \mathrm{C}$. The cell suspension used to inoculate the milk was also subjected to evaluation for $\beta$-galactosidase and lactate dehydrogenase activities. Cell suspensions, washed in $50 \mathrm{mM}$ Tris/HCl buffer, $\mathrm{pH} \mathrm{7,} \mathrm{and} \mathrm{concentrated,} \mathrm{were} \mathrm{subjected} \mathrm{to}$ mechanical disruption using a Precellys bead beater (Advanced Biotech). After centrifugation at $15000 \mathrm{~g}$ at $4{ }^{\circ} \mathrm{C}$, the protein content within total cell extract was measured using the Bradford method (Bradford, 1976), with BSA as the standard. $\beta$-Galactosidase activity was evaluated in $50 \mathrm{mM}$ Tris/ $\mathrm{HCl}$ buffer, $\mathrm{pH}$ 7, using $10 \mu \mathrm{g}$ protein and $0.7 \mathrm{mg}$ 2-nitrophenyl $\beta$-D-galactopyranoside $\mathrm{ml}^{-1}$ (SigmaAldrich). Samples were incubated at $37^{\circ} \mathrm{C}$ for $20 \mathrm{~min}$, and the $\beta$ galactosidase activity was expressed as absorbance units $\min ^{-1}$ ( $\mathrm{mg}$ of protein $)^{-1}$ by measuring the absorbance of $o$-nitrophenol at $420 \mathrm{~nm}$ [molar extinction coefficient $(\varepsilon) 18.30 \times 10^{3} 1 \mathrm{~mol}^{-1} \mathrm{~cm}^{-1}$ ]. One unit of enzyme activity is defined as the amount of enzyme required to produce $1 \mu \mathrm{mol}$ product $\mathrm{min}^{-1}$. The results are expressed as the means $( \pm S D)$ of four independent determinations. Lactate dehydrogenase activity was determined by measuring the rate of NADH oxidation at $340 \mathrm{~nm}\left(\varepsilon 6.22 \times 10^{3} 1 \mathrm{~mol}^{-1} \mathrm{~cm}^{-1}\right)$, essentially as described by Gaspar et al. (2007) and Garrigues et al. (1997). One unit of enzyme activity is defined as the amount of enzyme required to produce $1 \mu \mathrm{mol}$ product $\mathrm{min}^{-1}$. Lactate dehydrogenase activity is expressed as the mean $( \pm \mathrm{SD})$ of four independent determinations.

${ }^{13} \mathbf{C} /{ }^{12} \mathbf{C}$ stable isotope ratio experiments. S. thermophilus was grown in M17 broth for $16 \mathrm{~h}$ in the presence of urea or $\left[{ }^{13} \mathrm{C}\right]$ urea $(4 \mathrm{mM})$. Cells were collected by centrifugation, washed 10 times in distilled water and either: (i) lyophilized, and used for the determination of the ${ }^{13} \mathrm{C} /{ }^{12} \mathrm{C}$ stable isotope ratio; or (ii) subjected to a modified alkaline cell lysis protocol (Manachini et al., 1985), without RNase treatment. Total extracted nucleic acid was recovered in water, and used for the evaluation of ${ }^{13} \mathrm{C} /{ }^{12} \mathrm{C}$ stable isotope ratio by isotope ratio MS. The ${ }^{13} \mathrm{C} /{ }^{12} \mathrm{C}(\%)$ values obtained are expressed as the means of three independent determinations $( \pm \mathrm{SD})$.

Electron microscopy. Bacterial cells were collected by centrifugation $(150 \mathrm{~g})$, and the resulting pellet was processed for transmission electron microscopy. The extract treated bacterial cells were fixed in $2.5 \%$ glutaraldehyde, and later post-fixed with $1 \%$ osmium tetroxide (in $0.1 \mathrm{M}$ cacodylate buffer, $\mathrm{pH}$ 7.2) for $2 \mathrm{~h}$, at room temperature. After eliminating the remaining osmium tetroxide, the samples were dehydrated in a graduated cold ethanol series (35-100\%); each step was performed for about $10-15 \mathrm{~min}$, at room temperature. The fixed cells were embedded in Epon 812. Blocks were cut with an ultramicrotome (Ultracut; Reichert), and collected on nickel grids. Sections were post-stained with $5 \%$ uranyl acetate for $5 \mathrm{~min}$ at room temperature, and treated with lead citrate for $1 \mathrm{~min}$. Sections were observed and photographed with a Philips CM 12 electron microscope and a Zeiss 900.

2D Electrophoresis. Three independent biological replicates of each bacterial growth experiment were harvested at $18000 \mathrm{~g}$, at $4{ }^{\circ} \mathrm{C}$ for $10 \mathrm{~min}$, and quickly washed five times with cold PBS. Cellular pellets 
were suspended in a solution containing $8 \mathrm{M}$ urea, $4 \%$ CHAPS, $1 \%$ DTT, $10 \mathrm{mM}$ Tris/HCl, and a cocktail of protease inhibitors (GE Healthcare), and disrupted five times by sonication for $4 \mathrm{~min}$ at maximum power. Cell debris was removed by centrifugation at $18000 \mathrm{~g}$ at $20{ }^{\circ} \mathrm{C}$ for $60 \mathrm{~min}$. The supernatant was precipitated, and delipidated with cold tri- $n$-butyl phosphate:acetone:methanol $(1: 12: 1, \mathrm{v} / \mathrm{v})$ (Mastro \& Hall, 1999). Cellular pellets were resuspended in $8 \mathrm{M}$ urea, $4 \%$ CHAPS, $1 \%$ DTT, $10 \mathrm{mM}$ Tris/ $\mathrm{HCl}$ and $2 \%$ ampholine, $\mathrm{pH}$ 4.0-6.5, containing nuclease mix (GE Healthcare) to remove nucleic acids. The protein concentration within samples was determined using a 2-D Quant kit (GE Healthcare).

Home-made immobilized $\mathrm{pH}$ gradient (IPG) strips $(13 \mathrm{~cm})$, with a linear $\mathrm{pH}$ range of 4.0-5.5, were rehydrated overnight in a dedicated buffer ( $8 \mathrm{M}$ urea; $4 \%$, w/v, CHAPS; $1 \%$, v/v, DTT; $10 \mathrm{mM}$ Tris; $2 \%$, $\mathrm{w} / \mathrm{v}$, ampholine; $\mathrm{pH} 4.0-6.5)$. A $100 \mu \mathrm{g}$ quantity protein sample was loaded on to each IPG strip via cathodic cup loading. IEF was applied using an Ettan IPGphor IEF system (GE Healthcare) at $20{ }^{\circ} \mathrm{C}$, with a current of $160 \mu \mathrm{A}$ per strip. The following protocol was applied: $30 \mathrm{~V}$ $(4 \mathrm{~h}), 50 \mathrm{~V}(3 \mathrm{~h}), 100 \mathrm{~V}(3 \mathrm{~h}), 500 \mathrm{~V}(3 \mathrm{~h}), 1000 \mathrm{~V}(3 \mathrm{~h}), 3000 \mathrm{~V}$ $(3 \mathrm{~h}), 4000 \mathrm{~V}(3 \mathrm{~h}), 6000 \mathrm{~V}(3 \mathrm{~h})$ and $8000 \mathrm{~V}(8 \mathrm{~h})$. After the first dimension, IPG strips were equilibrated twice with a solution containing $6 \mathrm{M}$ urea, $2 \% \mathrm{SDS}, 50 \mathrm{mM}$ Tris/ $\mathrm{HCl}, \mathrm{pH} 8.8$, and $30 \%$ (v/v) glycerol, for $15 \mathrm{~min}$. To the first equilibrium, 1\% DTT was added; to the second equilibrium, $2.5 \%$ iodoacetamide and a trace of Bromophenol Blue were added. The second dimension was performed by the use of home-made $8-15 \%$ acrylamide gradient vertical SDS-PAGE slab gels $(13 \times 13 \times 0.1 \mathrm{~cm})$, using a Protean II xi cell (Bio-Rad); the gels were run at $15 \mathrm{~mA}$ per gel for $20 \mathrm{~min}$, and then at $50 \mathrm{~mA}$ per gel. Then, gels were stained with colloidal Coomassie Blue, and scanned with a Pharos FX Plus Laser Imaging System (Bio-Rad). 2D Electrophoresis was performed in triplicate for each sample. Image analysis was performed using ImageMaster 2D Platinum version 6.0.1 software (GE Healthcare). Images were analysed for detection and quantification of the spot intensities, gel matching and statistical analysis. To correct for overall intensity differences between the gels, each gel was normalized to the standard according to the total quantity of valid spots. Differential analysis was limited to spots that were either unique to one set of gels or changed in intensity by a factor of at least two. Within the experimental replicates of the same sample, no percentage volume variations higher than $15 \%$ were detected for the spots analysed.

MS analysis, and protein identification. Spots of interest were excised manually from 2D electrophoresis gels, destained, in-gel reduced, $S$-alkylated, and digested with trypsin, as previously reported (Talamo et al., 2003). Digests were extracted with $25 \mathrm{mM}$ $\mathrm{NH}_{4} \mathrm{HCO}_{3}$ : acetonitrile $(1: 1, \mathrm{v} / \mathrm{v})$ by sonication, and concentrated. Samples were desalted using $\mu$ ZipTipC18 pipette tips (Millipore) before MALDI-TOF MS analysis, and/or direct analysis by micro liquid chromatography coupled with electrospray ionization ion trap tandem mass spectrometry ( $\mu$ LC-ESI-IT-MS-MS).

Peptide digests were loaded on the MALDI target, together with $\alpha$ cyano-4-hydroxycinnamic acid as the matrix. Samples were analysed with a Voyager-DE PRO spectrometer (Applera), as previously reported (Rocco et al., 2006). Mascot software (Matrix Science) (Perkins et al., 1999) was used to identify spots from a NCBI nonredundant database by using peptide mass fingerprinting experiments in reflectron mode. Candidates with program scores $>79$ were further evaluated by the comparison with $M_{\mathrm{r}}$ and isoelectric point (pI) experimental values from $2 \mathrm{D}$ electrophoresis.

Peptide digests were also analysed by $\mu$ LC-ESI-IT-MS-MS using a LCQ Deca Xp Plus MS equipped with an electrospray source connected to a Phoenix 40 pump (ThermoFinnigan), as previously reported (Talamo et al., 2003; D'Ambrosio et al., 2006; Rocco et al., 2006). Proteins were identified by the SEQUEST algorithm (MacCoss et al., 2002) by comparison of tryptic peptide product ion mass spectra against those generated from a database containing the annotated S. thermophilus LMG 13811, CNRZ1066 and LMD-9 genome sequences (Bolotin et al., 2004; Makarova et al., 2006), together with trypsin and keratins. The SEQUEST parameters included selection of trypsin with up to two missed cleavage sites, and static and dynamic mass modification associated with cysteine carbamidomethylation and methionine oxidation, respectively. Identified proteins were ranked in ascending order according to consensus scores, and false-positive identifications were minimized by filtration against four of the following criteria: Xcorr $>2$, $\Delta \mathrm{Cn}>0.2, \mathrm{Sp}>400, \mathrm{rsp}<5$, ions $>30 \%$ (Link et al., 1999). Where appropriate, protein identifications were checked manually to provide for a false positive rate of $<1 \%$, using Xcorr and $\Delta C n$ values described and validated elsewhere (Peng et al., 2003). Proteins with more than two identified peptides were considered as reliably identified proteins.

\section{RESULTS}

The effect of $\mathrm{CO}_{2}$ availability on the metabolism of $S$. thermophilus was evaluated by growing strain DSM $20617^{\mathrm{T}}$ on solid medium in an anaerobic jar, under an enriched $\mathrm{CO}_{2}$ concentration $(18 \% \mathrm{v} / \mathrm{v})$ or under a $\mathrm{N}_{2}$ atmosphere. After incubation for $24 \mathrm{~h}$ at $37^{\circ} \mathrm{C}$, the biomass was collected, and analysed by electron microscopy and proteomic analysis. Prolonging the incubation to 36 or $48 \mathrm{~h}$ did not result in an increase in biomass yield; therefore, the cultures were considered to be in the stationary phase of growth after incubation for $24 \mathrm{~h}$. The choice of solid medium to perform the experiments reported in this study was dictated by the difficulty in obtaining complete removal of $\mathrm{CO}_{2}$ from liquid medium. Moreover, all the attempts to provide liquid medium that was $\mathrm{CO}_{2}$ free for the time necessary to perform the experiments were ineffective.

\section{Effect of $\mathrm{CO}_{2}$ availability on cell morphology}

Electron microscopy of $S$. thermophilus cells grown in the presence of different $\mathrm{CO}_{2}$ availabilities revealed significant differences in cell morphology. Under a $\mathrm{N}_{2}$ atmosphere, cells that were abnormally shaped were detected with high frequency. The cells were abnormally elongated, and were most probably the result of a defect in cell division (Fig. 2). When $S$. thermophilus was cultured under a $\mathrm{N}_{2}$ atmosphere on solid medium supplemented with $1 \mathrm{mM}$ urea, the normal ovoid shape was partially restored (Fig. 2d). This phenomenon is associated with the slow release of $\mathrm{CO}_{2}$ during the growth of the micro-organism in the presence of urea (Mora et al., 2004); in fact, it has been reported that bacterial urea amidohydrolase (EC 3.5.1.5) hydrolyses urea to $\mathrm{NH}_{3}$ and carbamate, which spontaneously decomposes to yield a second molecule of $\mathrm{NH}_{3}$ and $\mathrm{CO}_{2}$. The changes in cell morphology observed in the $\mathrm{CO}_{2}$-starved culture prompted us to investigate the metabolic activities involved in $\mathrm{CO}_{2}$ utilization.

\section{Role of the anaplerotic reactions catalysed by phosphoenolpyruvate carboxylase and carbamoyl-phosphate synthase in $\mathrm{CO}_{2}$ metabolism}

We have identified two main metabolic pathways involved in $\mathrm{CO}_{2}$ utilization from the annotated genomes of $S$. 
(a)

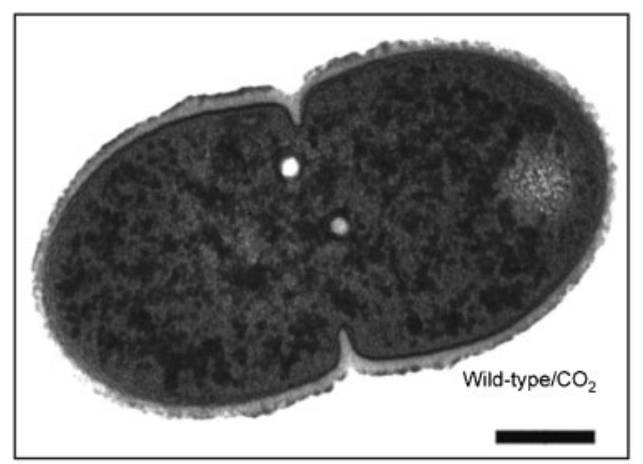

(d)

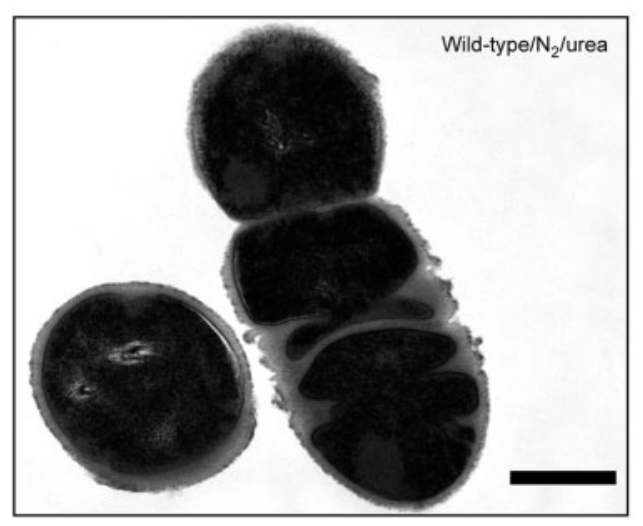

(b)

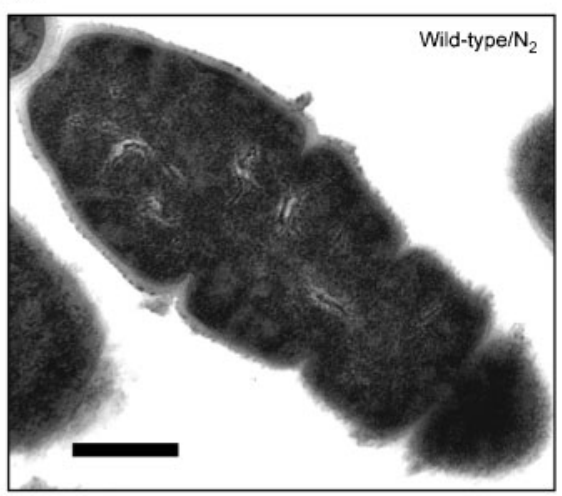

(c)

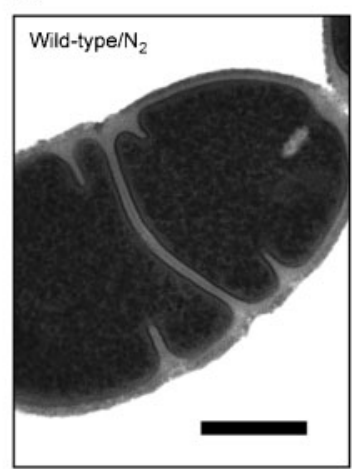

(f)

(e)

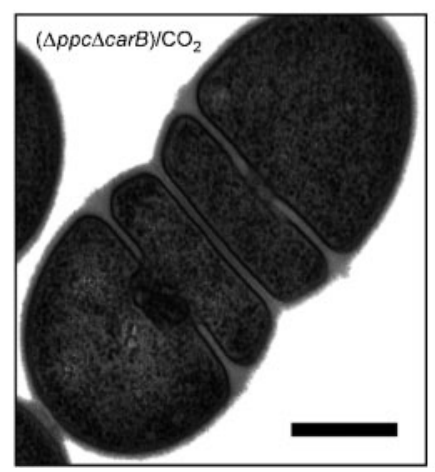

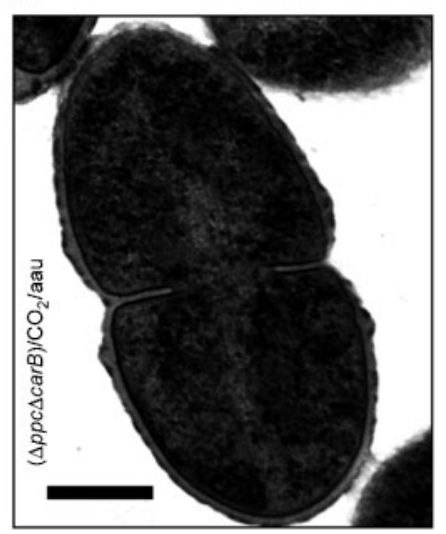

Fig. 2. Transmission electron micrographs showing $S$. thermophilus wild-type and $A 19(\Delta p p c \Delta c a r B)$ mutant after growth in $M 17$ medium under an enriched $\mathrm{CO}_{2}$ atmosphere and a $\mathrm{N}_{2}$ atmosphere. (a) Wild-type grown under enriched $\mathrm{CO}_{2}$. (b) and (c) Wildtype grown under $\mathrm{N}_{2}$. (d) Wild-type grown under $\mathrm{N}_{2}$ on medium supplemented with $1 \mathrm{mM}$ urea. (e) Mutant grown under enriched $\mathrm{CO}_{2}$. (f) Mutant grown under enriched $\mathrm{CO}_{2}$ on medium supplemented with aspartate, arginine and uracil (aau). Bars, $0.2 \mu \mathrm{m}$.

thermophilus genome (Bolotin et al., 2004; Hols et al., 2005); these pathways are governed by $\mathrm{PpC}$ and $\mathrm{CpS}$ (Fig. 1), and are involved in amino acid and pyrimidine biosynthesis. To understand the relevance of these pathways to bacterial metabolism, the double mutant $\mathrm{A} 19(\Delta p p c \Delta c a r B)$ of the wild-type DSM $20617^{\mathrm{T}}$, presenting inactivation of both $\mathrm{PpC}$ and CpS, was obtained from the strain $\mathrm{A} 18(\Delta p p c)$ (Arioli et al., 2007). On the basis of the reaction scheme shown in Fig. 1, and the data reported for strain A18 $(\Delta p p c)$, evaluation of the growth of mutant A19 on CDM revealed its expected auxotrophy for aspartic acid, arginine and uracil, which are the final products of the pathways governed by $\mathrm{PpC}$ and $\mathrm{CpS}$ (Fig. 3). Interestingly, the cell morphology of the mutant $\mathrm{A} 19(\Delta p p c \Delta c a r B)$ grown in the $\mathrm{CO}_{2}$-enriched atmosphere was very similar to that of the wild-type grown in the absence of $\mathrm{CO}_{2}$ (under a $\mathrm{N}_{2}$ atmosphere) (Fig. 2e). This observation underlined the fact that the two anaplerotic pathways inactivated in the double mutant have a central role in the $\mathrm{CO}_{2}$ metabolism of $S$. thermophilus. In fact, despite the high availability of $\mathrm{CO}_{2}$ in the growth environment, the mutant A19 was unable to use $\mathrm{CO}_{2}$ through the anaplerotic reactions based on PpC and CpS; on the other hand, the wild-type strain was unable to conduct its metabolism through the same enzymic reactions when cultured in the absence of $\mathrm{CO}_{2}$. In the light of these considerations, the stress conditions determining the abnormal cell morphology in the wild-type strain cultured under a $\mathrm{N}_{2}$ atmosphere could be due to the limited availability of aspartic acid, arginine and pyrimidine. This hypothesis was corroborated by the observation that the wild-type cell morphology was restored when the $\mathrm{A} 19(\Delta p p c \Delta c a r B)$ mutant was grown on M17 medium supplemented with aspartic acid, arginine and uracil (Fig. 2f). When the wild-type was grown under a $\mathrm{N}_{2}$ atmosphere on M17 medium supplemented with aspartic acid, arginine and uracil, no changes in cell morphology were observed. Therefore, we conclude that $\mathrm{CO}_{2}$ depletion in $S$. thermophilus determines arginine, aspartic acid and uracil auxotrophy.

\section{$\mathrm{CO}_{2}$ depletion, arginine, aspartic acid and uracil auxotrophy, and urea metabolism, in S. thermophilus}

To confirm our hypothesis on $\mathrm{CO}_{2}$-depletion-dependent auxotrophy for arginine, aspartate and uracil, S. thermophilus 
wild-type was grown on CDM, CDM supplemented with arginine, aspartate and uracil (CDM-aau), CDM supplemented with sodium bicarbonate $\left(\mathrm{CDM}-\mathrm{HCO}_{3}\right)$, and $\mathrm{CDM}$ supplemented with urea (CDM-urea), either in an enriched $\mathrm{CO}_{2}$ atmosphere or in a $\mathrm{N}_{2}$ atmosphere. Growth was measured as the mean $( \pm \mathrm{SD})$ of three cell density $\left(\mathrm{OD}_{600}\right)$ measurements. After incubation for $24 \mathrm{~h}$ at $37{ }^{\circ} \mathrm{C}$, bacterial growth was detected on all the media incubated in a

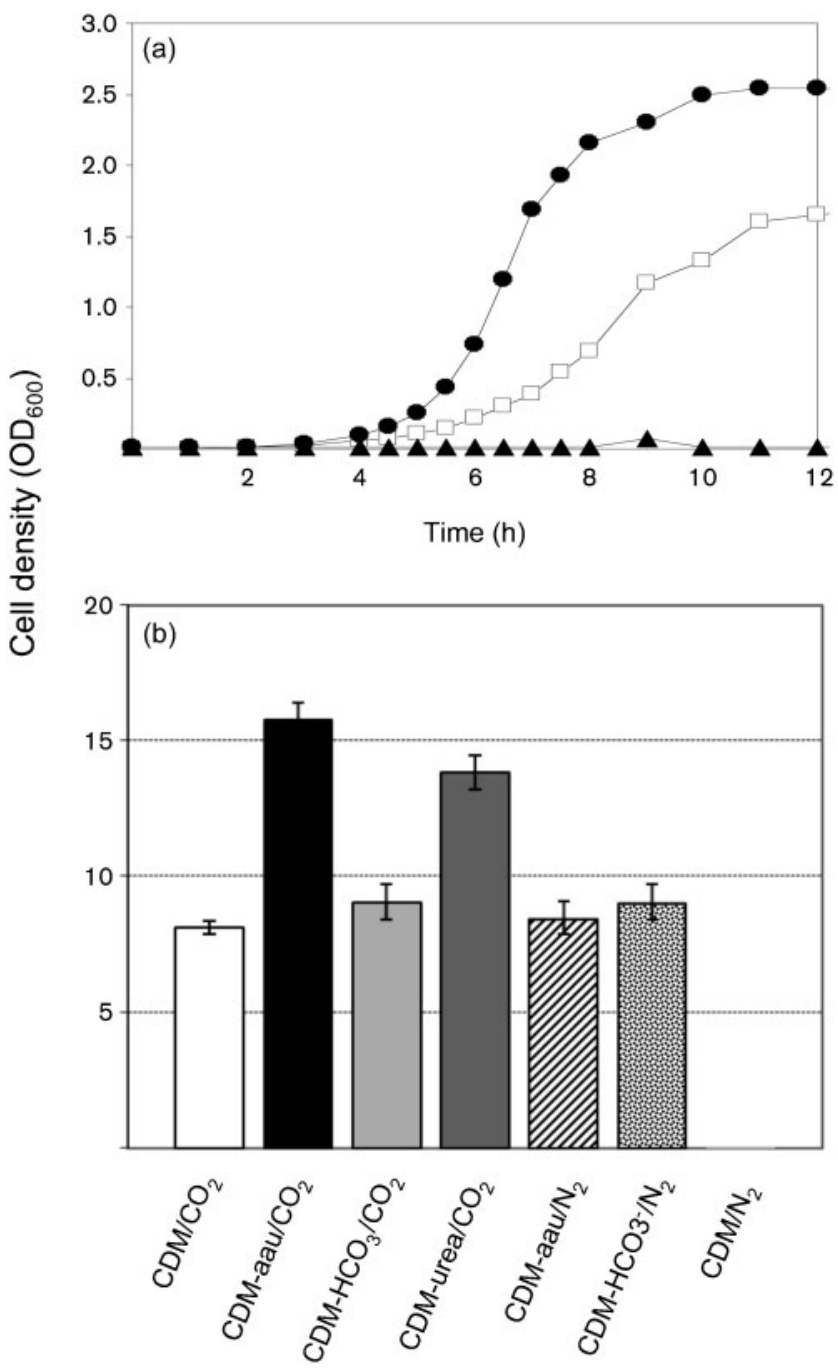

Fig. 3. Growth of $S$. thermophilus wild-type (0) and mutant $\mathrm{A} 19(\Delta p p c \Delta c a r B)(\boldsymbol{\Delta})$ in $\mathrm{CDM}$, and growth of the mutant in CDM supplemented with $2.25 \mathrm{mM}$ aspartate, $0.1 \mathrm{mM}$ arginine and $0.2 \mathrm{mM}$ uracil $(\square)$. The values are the means of three replicates, and for each value the SD was $<0.05 \mathrm{OD}_{600}$ units. (b) Growth of $S$. thermophilus wild-type in CDM, CDM supplemented with $2.25 \mathrm{mM}$ L-Asp, $0.1 \mathrm{mM}$ L-Arg and $0.2 \mathrm{mM}$ uracil (CDM-aau), $\mathrm{CDM}$ supplemented with $5 \mathrm{mM} \mathrm{NaHCO}\left(\mathrm{CDM}_{3}-\mathrm{HCO}_{3}\right)$, and CDM supplemented with $5 \mathrm{mM}$ urea (CDM-urea). The experiments were performed under a carbon dioxide or nitrogen atmosphere as indicated. All CDM cultures were repeated three times. SD values are indicated.
$\mathrm{CO}_{2}$-enriched atmosphere, but only on CDM-aau and $\mathrm{CDM}^{-\mathrm{HCO}_{3}}$ under a $\mathrm{N}_{2}$ atmosphere (Fig. 3). When $S$. thermophilus was grown on $\mathrm{CDM}$ under $\mathrm{N}_{2}$, no bacterial growth was detected. These results clearly suggest that $\mathrm{CO}_{2}$ is essential to feed the anaplerotic reactions governed by $\mathrm{PpC}$ and $\mathrm{CpS}$, and therefore for the biosynthesis of arginine, pyrimidine and aspartate. Interestingly, aspartate, arginine and uracil auxotrophy generated by $\mathrm{CO}_{2}$ depletion (in a $\mathrm{N}_{2}$ atmosphere) did not occur when CDM was supplemented with bicarbonate (Fig. 3). The addition of urea did not allow the growth of the strain on CDM under $\mathrm{N}_{2}$. The lack of growth on CDM-urea under $\mathrm{N}_{2}$ was explained by the presence of a level of urease activity in the inoculated cells that was unable to hydrolyse the urea supplement in the medium and, therefore, to produce enough $\mathrm{CO}_{2}$ to feed the anaplerotic reactions. It is known that urease biogenesis is strongly induced in the early stage of growth when the environmental $\mathrm{pH}$ reaches a subacid value, and it decreases in the late-exponential phase of growth (Mora et al., 2005). In this context, it is reasonable that the cells inoculated on CDMurea under $\mathrm{N}_{2}$, unable to grow as result of their auxotrophy for aspartate, arginine and uracil, did not acidify the medium to a level sufficient for the induction of urease biogenesis.

The addition of bicarbonate or urea to the medium resulted in a significant increment of growth yield when $S$. thermophilus was cultivated under an enriched $\mathrm{CO}_{2}$ atmosphere (Fig. 3). The growth enhancement observed on $\mathrm{CDM}$-urea under a $\mathrm{CO}_{2}$ atmosphere suggested that $\mathrm{CO}_{2}$ generated by urease activity may be directly metabolized by the micro-organism. When $S$. thermophilus was grown on M17 medium supplemented with $\left[{ }^{13} \mathrm{C}\right]$ urea, the evaluation of the ${ }^{13} \mathrm{C} /{ }^{12} \mathrm{C}$ stable isotope ratio in the biomass, and in the nucleic acid extracts, revealed that labelled $\mathrm{CO}_{2}$ generated by urea hydrolysis was actively metabolized. In fact, a significant increase in the ${ }^{13} \mathrm{C} /{ }^{12} \mathrm{C}$ ratio was detected in the biomass of the cells fed with $\left[{ }^{13} \mathrm{C}\right]$ urea $\left({ }^{13} \mathrm{C} /{ }^{12} \mathrm{C} \%\right.$ value equal to $-23.14 \pm 0.7$, mean $\pm \mathrm{SD})$ compared with those fed with standard urea $\left({ }^{13} \mathrm{C} /{ }^{12} \mathrm{C} \%\right.$ value equal to $-27.10 \pm 0.7)$. Likewise, the evaluation of the ${ }^{13} \mathrm{C} /{ }^{12} \mathrm{C}$ ratio carried out on a total nucleic acid extraction revealed a significant increase of ${ }^{13} \mathrm{C}$ in the nucleic acids derived from cells fed with $\left[{ }^{13} \mathrm{C}\right]$ urea $\left({ }^{13} \mathrm{C} /{ }^{12} \mathrm{C} \%\right.$ value equal to $+17.04 \pm 0.5)$ compared with those derived from cells fed with standard urea $\left({ }^{13} \mathrm{C} /{ }^{12} \mathrm{C} \%\right.$ value equal to $-23.49 \pm 0.7)$.

\section{Proteomic analysis of wild-type S. thermophilus and $A 19(\Delta p p c \Delta c a r B)$ mutant grown under different gas atmospheres}

Proteomic approaches have been widely used to monitor global changes of gene expression patterns during bacterial growth/starvation, or following environmental stresses, and they have provided a comprehensive view in understanding microbial physiology or adaptation to external stimuli (Arena et al., 2006; Bernhardt et al., 2003; Eymann et al., 2004; Salzano et al., 2007). Thus, the effect of different $\mathrm{CO}_{2}$ 
availability on the proteome of $S$. thermophilus was evaluated by growing the wild-type strain and the $\mathrm{A} 19(\Delta p p c \Delta c a r B)$ mutant in an enriched $\mathrm{CO}_{2}$ atmosphere or a $\mathrm{N}_{2}$ atmosphere. The cells were collected from solid M17 medium after incubation for $24 \mathrm{~h}$, and total protein extracts were separated by $2 \mathrm{D}$ electrophoresis in the $\mathrm{pH}$ range 4.5-5.5. Almost 540 protein spots were detected in the proteomic map of the wild-type strain grown under the $\mathrm{CO}_{2}$ atmosphere (data not shown). 2D Electrophoresis maps from the wild-type strain and the $A 19(\Delta p p c \Delta c a r B)$ mutant grown in an enriched $\mathrm{CO}_{2}$ atmosphere or a $\mathrm{N}_{2}$ atmosphere were subjected to densitometric analysis to determine quantitative differences within bacterial proteomic repertoires. Protein spots that varied among the experimental conditions, and some that were constant (used as a reference), were excised from the gels, and identified by combining peptide mass fingerprinting MALDI-TOF and $\mu$ LC-ESI-IT-MS-MS approaches (Table 1).

Despite the relevant effects of $\mathrm{CO}_{2}$ availability on bacterial morphology, only a limited number of proteins appeared to be up- or downregulated in the wild-type strain grown in the enriched $\mathrm{CO}_{2}$ atmosphere compared with cultivation under $\mathrm{N}_{2}$ (wild-type/ $\mathrm{CO}_{2}$ versus wild-type/ $\mathrm{N}_{2}$ ) (Fig. $4 \mathrm{a}$ ). Interestingly, most of the proteins upregulated in the $\mathrm{CO}_{2}$ enriched atmosphere are involved in bioenergy metabolism (Fig. 4a); they were identified as glycolytic enzymes, such as glyceraldehyde-3-phosphate dehydrogenase (spot 14), 6phosphofructokinase (spot 19), triosephosphate isomerase (spot 25) and L-lactate dehydrogenase (spot 18), confirming that glycolysis and homolactic fermentation were actively stimulated in presence of $\mathrm{CO}_{2}$. The activation of bioenergy metabolism in the presence of a high availability of $\mathrm{CO}_{2}$ was in agreement with the large increment of biomass dry weight obtained when S. thermophilus was grown under the same experimental conditions, i.e. $72 \%$ of cell dry weight under $\mathrm{CO}_{2}(0.1581 \mathrm{~g})$ compared with the cell biomass obtained under a $\mathrm{N}_{2}$ atmosphere $(0.0437 \mathrm{~g})$.

It is also worth mentioning the gas-dependent behaviour of the two HPr isoforms present within the bacterial proteomic maps of the wild-type strain. The more acidic isoform (spot 38) was dominant in the $\mathrm{CO}_{2}$-enriched atmosphere, while the more basic isoform (spot 39) was more abundant in cells cultured under a $\mathrm{N}_{2}$ atmosphere (Figs $4 \mathrm{a}$ and $5 \mathrm{a}, \mathrm{b}$ ). HPr is a phosphate-transfer protein of the phosphoenolpyruvate phosphotransferase system involved in the uptake of carbohydrates, and it regulates lactose permease (LacS) expression and activity, which contribute to the fast cellular response to alterations in the external lactose concentration. In several bacteria, Hpr, together with the catabolite control protein $\mathrm{CcpA}$, also play a central role in a transcriptional regulation system that ensures an efficient rate of carbohydrate uptake. The serine-phoshorylated form of $\mathrm{HPr}[\mathrm{HPr}(\mathrm{Ser}-\mathrm{P})]$, dominant in the exponential phase of growth of various bacteria, acts as a co-repressor of CcpA, and controls transcriptional repression of lacSZ (Gunnewijk \& Poolman, 2000a; van den Bogaard et al., 2000); the histidine-phosphorylated form of $\mathrm{HPr}[\mathrm{HPr}(\mathrm{His}-\mathrm{P})]$, dominant in the stationary phase, phosphorylates the hydrophilic IIA domain of LacS, thereby affecting the transport (Gunnewijk \& Poolman, $2000 \mathrm{~b})$. After the mid-exponential phase of growth, there is an increase in the level of $\operatorname{HPr}($ His-P) and a decrease in the level of $\operatorname{HPr}(\mathrm{Ser}-\mathrm{P})$, resulting in increased transport activity, and an increase in the biosynthesis of LacS, thereby compensating for the decrease in the level of substrate (lactose), and the increase in the level of inhibitory end product (galactose) in the medium (Gunnewijk \& Poolman, 2000a). Similar to problems encountered during analysis of other lactic acid bacteria, our attempts to identify structural differences between spots 38 and 39 failed, probably as result of signal suppression phenomena during MS analysis of phosphopeptides. Based on their pI differences, relative stability under 2D electrophoresis, and previous observations on HPr counterparts from Lactococcus lactis (Palmfeldt et al., 2004), spot 38 was identified as $\mathrm{HPr}($ Ser-P), while spot 39 was associated to $\mathrm{HPr}($ His-P) and $\mathrm{HPr}$ (Fig. 5a, b).

All the proteins upregulated in the wild-type strain under a $\mathrm{N}_{2}$-enriched atmosphere displayed a chaperone activity, or behaved like folding templates, towards denatured polypeptides; in particular, they were identified as GroEL, DnaK, GrpE and translation elongation factor Tu (spots 7, 5, 28 and 10, respectively) (Fig. 4a, Table 1). Their increased abundance during the response of $S$. thermophilus and other lactic acid bacteria to various environmental stresses has been reported, and it has been associated with an attempt by the bacterium to protect itself from the accumulation of toxic protein waste (Arena et al., 2006).

Diagrams and data displayed in Figs 1-3 reveal that the anaplerotic reactions inactivated in the mutant $\mathrm{A} 19(\Delta p p c \Delta c a r B)$ have a potentially high relevance to the $\mathrm{CO}_{2}$ metabolism of $S$. thermophilus. To corroborate this hypothesis, the proteome of the wild-type grown under $\mathrm{CO}_{2}$ was compared with the proteome obtained by growing the A19 mutant under the same experimental conditions. This comparison revealed that a number of proteins were up- or downregulated in the mutant, and these proteins were very similar to those whose expression level changed in the wildtype strain growing in $\mathrm{N}_{2}$ (Fig. 4, Table 1). In fact, a similar quantitative trend was observed for glyceraldehyde-3phosphate dehydrogenase (spot 14), 6-phosphofructokinase (spot 19), L-lactate dehydrogenase (spot 18), DnaK (spot 5), GrpE (spot 28), translation elongation factor Tu (spot 10) and $\mathrm{HPr}$ (spots 38 and 39). The basic isoform of HPr (spot 39) was dominant in the mutant in the two atmospheric conditions used (Fig. 5). Considering that the wild-type and A19 mutant were cultured under the same experimental conditions, the observed relative abundance of the two HPr isoforms seems to reflect the similar effect on energy metabolism induced by $\mathrm{CO}_{2}$ depletion as a result of the presence of $\mathrm{N}_{2}$ (wild-type/ $\mathrm{N}_{2}$ ) or the inactivation of the anaplerotic reactions catalysed by $\mathrm{PpC}$ and $\mathrm{CpS}$ $\left[\mathrm{A} 19(\Delta p p c \Delta c a r B) / \mathrm{CO}_{2}\right]$ (Fig. 5). On the other hand, the abundance of specific proteins was changed in the mutant 
Table 1. Proteins identified in the $2 \mathrm{D}$ electrophoresis maps of $S$. thermophilus wild-type strain and $A 19$ mutant grown under different gas atmospheres

\begin{tabular}{|c|c|c|c|c|c|c|c|c|}
\hline Spot & Protein & $\mathrm{pI}^{*}$ & $M_{\mathbf{r}}^{*}$ & $\begin{array}{l}\text { Swiss-Prot } \\
\text { code }\end{array}$ & Strain & Method $\dagger$ & Peptides & $\begin{array}{c}\text { Sequence } \\
\text { coverage } \\
(\%)\end{array}$ \\
\hline 2 & $\begin{array}{l}\text { ATP-binding subunit of Clp protease and DnaK/DnaJ } \\
\text { chaperones }\end{array}$ & 5.08 & 77153 & Q03J94 & LMD-9 & PMF & $7 / 9$ & 14 \\
\hline 4 & Molecular chaperone, DNAK & 4.62 & 64756 & Q03MR6 & LMD-9 & PMF & $26 / 35$ & 55 \\
\hline 5 & Molecular chaperone, DNAK & 4.62 & 64756 & Q03MR6 & LMD-9 & PMF & $11 / 12$ & 25 \\
\hline 6 & $60 \mathrm{kDa}$ chaperonin, GroEL & 4.70 & 56923 & Q03MK3 & LMD-9 & PMF & $21 / 30$ & 53 \\
\hline 7 & $60 \mathrm{kDa}$ chaperonin, GroEL & 4.70 & 56923 & Q03MK3 & LMD-9 & PMF & $37 / 49$ & 61 \\
\hline 8 & FKBP-type peptidyl-prolyl cis-trans isomerase & 4.41 & 46682 & Q03MQ9 & LMD-9 & PMF & $16 / 17$ & 35 \\
\hline 12 & Ribosomal protein $\mathrm{S} 6$ & 4.97 & 11111 & Q03IV3 & LMD-9 & PMF & $9 / 21$ & 84 \\
\hline 13 & Enolase & 4.72 & 46977 & Q03LI0 & LMD-9 & PMF & $27 / 35$ & 69 \\
\hline 14 & Glyceraldehyde-3-phosphate dehydrogenase & 5.26 & 36022 & Q03IS2 & LMD-9 & PMF & $14 / 20$ & 32 \\
\hline 15 & Glyceraldehyde-3-phosphate dehydrogenase & 5.26 & 36022 & Q03IS2 & LMD-9 & PMF & $12 / 17$ & 32 \\
\hline 16 & Glyceraldehyde-3-phosphate dehydrogenase & 5.26 & 36022 & Q03IS2 & LMD-9 & PMF & $17 / 23$ & 44 \\
\hline 17 & Glyceraldehyde-3-phosphate dehydrogenase & 5.26 & 36022 & Q03IS2 & LMD-9 & PMF & $8 / 9$ & 29 \\
\hline 18 & L-Lactate dehydrogenase & 4.92 & 35429 & Q03K30 & LMD-9 & PMF & $6 / 9$ & 28 \\
\hline 19 & 6-Phosphofructokinase & 5.09 & 35982 & Q03KB7 & LMD-9 & PMF & $24 / 29$ & 62 \\
\hline 20 & Fructose-1-phosphate kinase & 4.77 & 32541 & Q5M169 & CNRZ1066 & PMF & $6 / 8$ & 20 \\
\hline 21 & $\begin{array}{l}\text { ABC-type transport system involved in Fe-S cluster } \\
\text { assembly, ATPase component }\end{array}$ & 4.95 & 33451 & Q03MN3 & LMD-9 & PMF & $11 / 12$ & 37 \\
\hline 30 & Single-stranded DNA-binding protein & 5.01 & 18680 & Q03IV4 & LMD-9 & PMF & $9 / 9$ & 48 \\
\hline 31 & 50S Ribosomal protein L5 & 9.34 & 19830 & Q03IG3 & LMD-9 & PMF & $7 / 7$ & 48 \\
\hline 32 & Transcription elongation factor greA & 4.65 & 17443 & Q03MH4 & LMD-9 & PMF & $6 / 9$ & 51 \\
\hline 33 & DNA-binding ferritin-like protein & 4.59 & 19221 & Q03LA4 & LMD-9 & PMF & $6 / 6$ & 34 \\
\hline 34 & $10 \mathrm{kDa}$ Chaperonin & 4.56 & 9912 & Q03MK4 & LMD-9 & PMF & $8 / 20$ & 66 \\
\hline 35 & 50S Ribosomal protein L10 & 5.36 & 17463 & Q03LT2 & LMD-9 & PMF & $8 / 10$ & 41 \\
\hline 36 & 30S Ribosomal protein S17 & 9.92 & 10027 & Q03IG0 & LMD-9 & MS/MS & 2 & 24 \\
\hline 36 & Ribosomal protein L18 & 10.40 & 12923 & Q03IG7 & LMD-9 & MS/MS & 3 & 32 \\
\hline 36 & 50S Ribosomal protein L19 & 10.78 & 13146 & Q03KD6 & LMD-9 & MS/MS & 4 & 25 \\
\hline 36 & 50S Ribosomal protein L21 & 9.86 & 11184 & Q03M33 & LMD-9 & MS/MS & 2 & 29 \\
\hline 37 & Ribosomal protein L7/L12 & 4.42 & 12360 & Q03LT1 & LMD-9 & PMF & $9 / 13$ & 74 \\
\hline 38 & Phosphotransferase system, HPr-related protein & 4.88 & 8919 & Q03K41 & LMD-9 & PMF & $5 / 9$ & 41 \\
\hline 39 & Phosphotransferase system, HPr-related protein & 4.88 & 8919 & Q03K41 & LMD-9 & PMF & $7 / 12$ & 44 \\
\hline 40 & Ribosomal protein S15P/S13E & 10.18 & 10517 & Q03MP3 & LMD-9 & PMF & $14 / 26$ & 64 \\
\hline
\end{tabular}

*Theoretical values.

$\uparrow \mathrm{PMF}$, Peptide mass fingerprinting. 


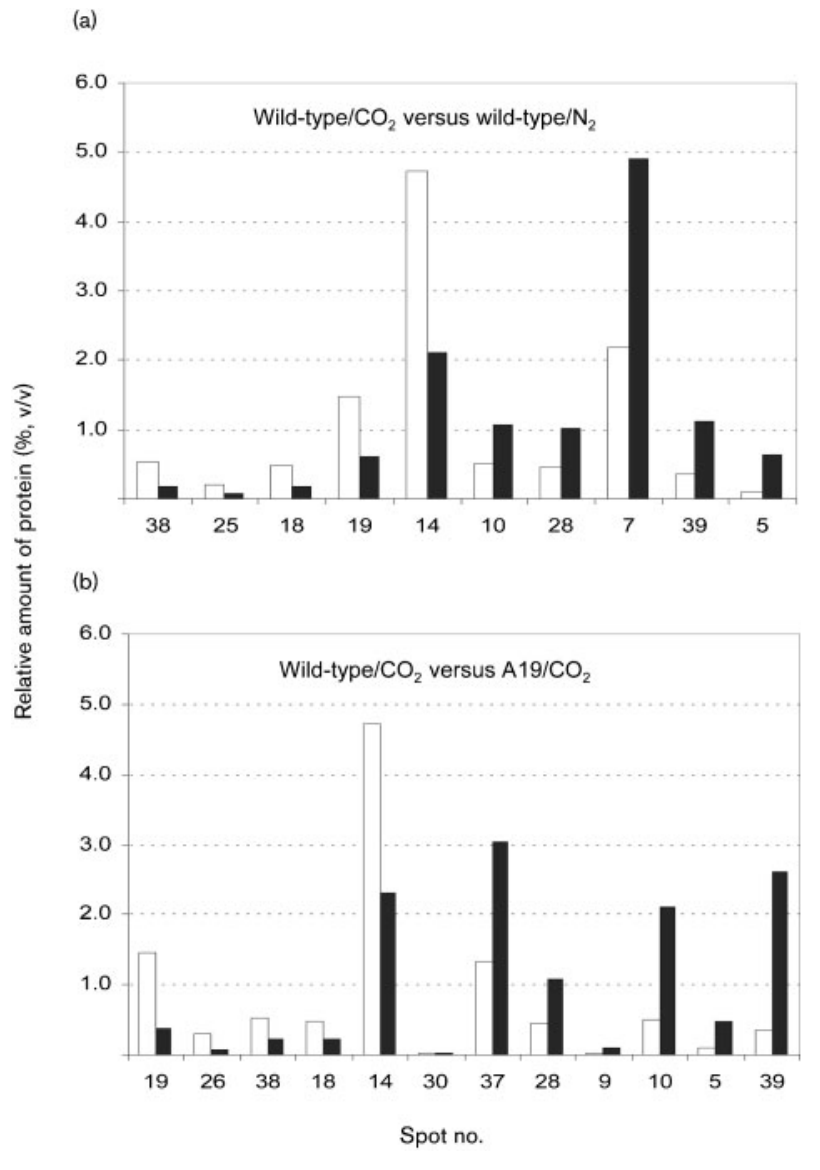

Fig. 4. Graphical representation of proteins differentially regulated in wild-type and $S$. thermophilus cells grown in different atmospheres. (a) The wild-type grown an enriched $\mathrm{CO}_{2}$ atmosphere (white bars) and a $\mathrm{N}_{2}$ atmosphere (black bars). (b) The wild-type (white bars) and mutant $A 19(\Delta p p c \Delta c a r B)$ (black bars) cultures grown in enriched $\mathrm{CO}_{2}$ atmosphere. No percentage volume variations higher than $15 \%$ were detected for the spots analysed within three experimental replicates of the same sample.

(Fig. 4); these proteins were putative uncharacterized protein str1986 (spot 26), single-stranded DNA-binding protein (spot 30), ribosomal protein L7/L12 (spot 37), and an uncharacterized conserved protein (spot 9). Putative uncharacterized protein str1986 belongs to a family of small proteins associated with alkaline shock response, and it was downregulated in the mutant A19. Single-stranded DNAbinding protein, ribosomal protein L7/L12 and the uncharacterized conserved protein were upregulated; the reason for their abundance in a mutant auxotroph for arginine, aspartic acid and uracil is not known at present.

\section{Milk acidification, $\beta$-galactosidase and lactate dehydrogenase activity of $S$. thermophilus grown under different gas atmospheres}

Gel densitometric analysis of some glycolytic enzymes and Llactate dehydrogenase in the wild-type strain suggested that glycolysis and homolactic fermentation were actively stimulated in the presence of an enriched $\mathrm{CO}_{2}$ atmosphere compared with a $\mathrm{N}_{2}$ atmosphere (Fig. 4a). On the other hand, the observed prevalence of $\operatorname{HPr}($ Ser-P) in cells grown in $\mathrm{CO}_{2}$ suggested that, under this condition, the culture was in a status of high energy (Fig. 5). Otherwise, the high prevalence of $\mathrm{HPr}($ His-P) in the proteome of the culture grown under a $\mathrm{N}_{2}$ atmosphere reflected a low level of energy status of the culture. According to observations by others (van den Bogaard et al., 2000), the relative amount of $\operatorname{HPr}($ Ser-P) and its interaction with CcpA should result in an increase of lactose transport efficiency, and in lacSZ operon derepression, and in $l d h$ repression. On the basis of these considerations, the milk acidification rate of cells grown under the two gas atmospheres was evaluated. The results obtained revealed that cells grown under a $\mathrm{N}_{2}$ atmosphere showed a significantly higher acidification rate compared with cells grown in enriched $\mathrm{CO}_{2}$ atmosphere (Fig. 6a). In fact, cells grown under $\mathrm{N}_{2}$ were able to acidify reconstituted pasteurized milk to a $\mathrm{pH}$ value below $5(4.90 \pm 0.03$, mean $\pm \mathrm{SD})$ after $10 \mathrm{~h}$ of incubation at $37{ }^{\circ} \mathrm{C}$, while cells grown in $\mathrm{CO}_{2}$ reached $\mathrm{pH} 4.96 \pm 0.06$ after $24 \mathrm{~h}$ of incubation.

To substantiate the effect of $\mathrm{CO}_{2}$ availability on the energy metabolism of $S$. thermophilus in milk, and the role of $\mathrm{HPr}($ Ser-P) on the regulation of lacSZ operon and $l d h$, biomass samples used to inoculate milk samples were also subjected to $\beta$-galactosidase and lactate dehydrogenase activity measurements. Wild-type cells grown under $\mathrm{N}_{2}$ showed a $\beta$-galactosidase activity $\left(252 \pm 12 \mathrm{U} \mathrm{mg}^{-1}\right.$, mean \pm SD) that was more than twofold higher than cells growth under enriched $\mathrm{CO}_{2}\left(113 \pm 9 \mathrm{U} \mathrm{mg}^{-1}\right)$. Conversely, the lactate dehydrogenase activity showed the higher values in wild-type cells grown under $\mathrm{CO}_{2}\left(3593 \pm 359 \mathrm{U} \mathrm{mg}^{-1}\right)$, while in cells grown under $\mathrm{N}_{2}$ this enzymic activity was $60 \%$ lower $\left(2144 \pm 214 \mathrm{U} \mathrm{mg}^{-1}\right)$. Unlike the wild-type, the basic isoform of HPr (Fig. 5) was dominant in the A19 mutant independent of the atmospheric composition used for bacterial growth (Fig. 5). For these reasons, it was not surprising to find that $\beta$-galactosidase and lactate dehydrogenase activity values measured for mutant A19 $(\Delta p p c \Delta c a r B)$ were the same irrespective of the gas composition used for micro-organism growth ( $\beta$-galactosidase: $298 \pm 12$ and $297 \pm 15 \mathrm{U} \mathrm{mg}^{-1}$; lactate dehydrogenase: $3577 \pm 360$ and $3715 \pm 420 \mathrm{U} \mathrm{mg}^{-1}$; in $\mathrm{N}_{2}$ and $\mathrm{CO}_{2}$, respectively). Interestingly, activities for both enzymes measured in A19 cells were higher than those measured for wild-type cells. The reason for the upregulation of these enzymes in mutant $\mathrm{A} 19(\Delta p p c \Delta c a r B)$ is not known at present, and needs further investigation.

\section{DISCUSSION}

Despite the industrial importance of $S$. thermophilus in dairy fermentation processes, the effect of $\mathrm{CO}_{2}$ on the overall metabolism of this micro-organism has been poorly investigated (Louaileche et al., 1993, 1996; Arioli et al., 2007). In this study, the relevance of $\mathrm{CO}_{2}$ metabolism in $S$. 
(a)

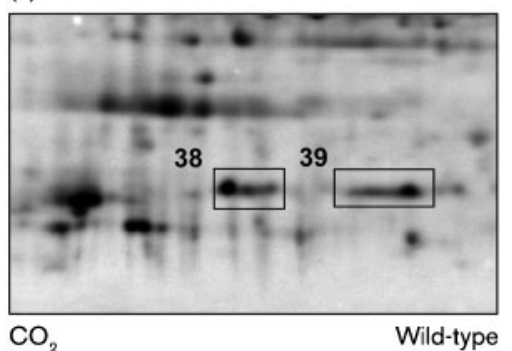

(c)

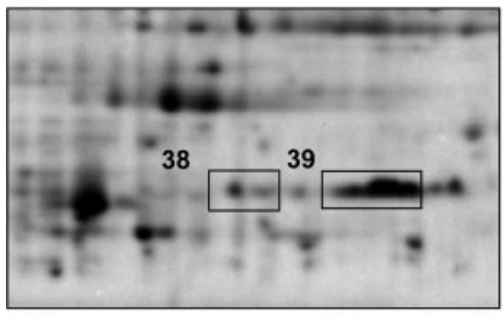

$\mathrm{CO}_{2}$
$\mathrm{A} 19(\Delta p p c \Delta c a r B)$ (b)

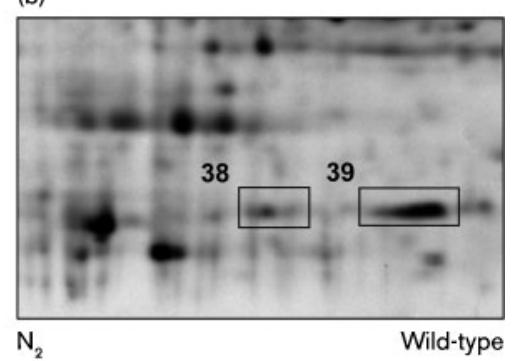

(d)

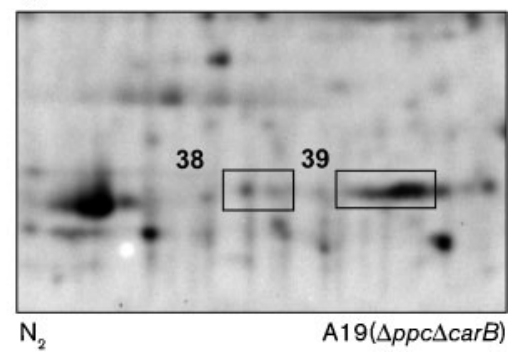

Fig. 5. Cropped images from 2D electrophoresis highlighting the distribution of the $\mathrm{HPr}$ isoforms in the proteomic map of $S$. thermophilus cells grown in different atmospheres. Wild-type $S$. thermophilus cells grown under (a) enriched $\mathrm{CO}_{2}$, and (b) $\mathrm{N}_{2}$. $\mathrm{A} 19(\Delta p p c \Delta c a r B)$ mutant grown under (c) enriched $\mathrm{CO}_{2}$, and (d) $\mathrm{N}_{2}$. Spots 38 and 39 were tentatively identified as $\mathrm{HPr}($ Ser-P) and $\mathrm{HPr}(\mathrm{His}-\mathrm{P}) / \mathrm{HPr}$, respectively. thermophilus was studied by evaluating the cell morphology and the proteomic repertoire of cultures grown under atmospheres with a different gas composition. Unlike most lactic acid bacteria, $S$. thermophilus maintains several biosynthetic pathways involved in amino acid and pyrimidine synthesis that are in some cases governed by anaplerotic reactions using $\mathrm{CO}_{2}$ as a substrate. Previous studies have reported that the metabolic pathway involved in aspartate biosynthesis (Fig. 1) has an essential role for the optimal growth of S. thermophilus in milk (Arioli et al., 2007), thus revealing the importance of $\mathrm{CO}_{2}$ in the general metabolism of this bacterium. For these reasons, a double mutant, in

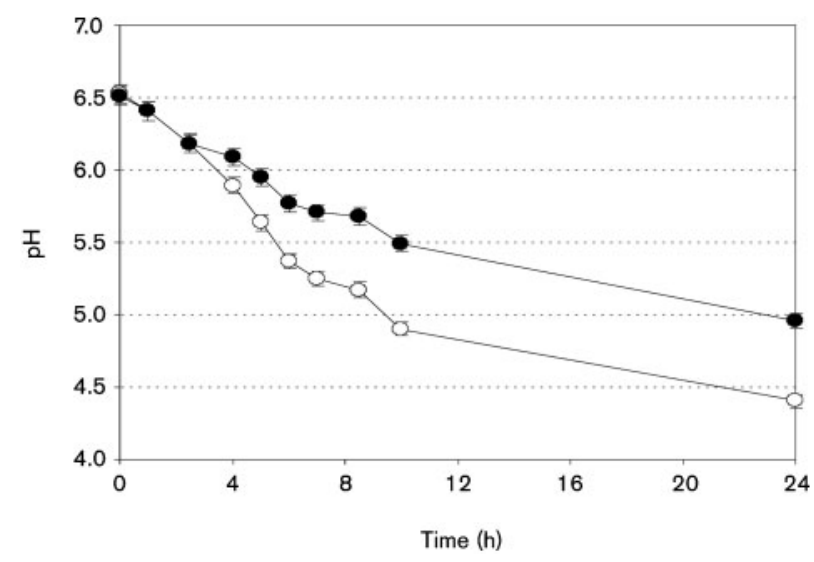

Fig. 6. Acidification curves of milk samples inoculated with $S$. thermophilus wild-type cells grown for $24 \mathrm{~h}$ at $37^{\circ} \mathrm{C}$ in an enriched $\mathrm{CO}_{2}$ atmosphere $(\bullet)$ and under $\mathrm{N}_{2}(\bigcirc)$. The values are the means of three replicates, and for each value the SD was $<0.08 \mathrm{pH}$ units. which the genes encoding $\mathrm{PpC}$ and $\mathrm{CpS}$ were inactivated, was constructed, and compared with the wild-type strain.

A limited $\mathrm{CO}_{2}$ availability for $S$. thermophilus resulted in a marked alteration in cell morphology, and a notable reduction in biomass production. The stress condition induced by $\mathrm{CO}_{2}$ starvation was evident from the dramatic changes in cell morphology of $S$. thermophilus cells grown under $\mathrm{N}_{2}$ (Fig. 2), when compared with those grown under the enriched $\mathrm{CO}_{2}$ atmosphere. Abnormally elongated $S$. thermophilus cells have been observed in a $\operatorname{rec} A$ mutant subjected to heat shock stress, and in a $\operatorname{rec} A$ mutant of Bacillus subtilis in response to nutrient starvation (Sciochetti et al., 2001; Giliberti et al., 2002). Interestingly, the abnormal $S$. thermophilus cell morphology characterizing the culture grown under a $\mathrm{N}_{2}$ atmosphere was similar to the cell morphology of the mutant $\mathrm{A} 19(\Delta p p c \Delta c a r B)$ grown under a $\mathrm{CO}_{2}$ atmosphere, but was unable to use the inorganic carbon as a result of the genetic inactivation of $\mathrm{PpC}$ and $\mathrm{CpS}$ activity. Therefore, it was argued that the anaplerotic reactions catalysed by $\mathrm{PpC}$ and $\mathrm{CpS}$ have a key role in the $\mathrm{CO}_{2}$ metabolism of $S$. thermophilus. Moreover, the normal ovoid-shaped cell morphology of $S$. thermophilus was restored in the culture grown in $\mathrm{N}_{2}$, but only when the medium was supplemented with pyrimidine and the amino acid end products of the biosynthetic pathways governed by $\mathrm{CpS}$ and $\mathrm{PpC}$ (Fig. 1), or when the medium was supplemented with sodium bicarbonate. Interestingly, the normal cell morphology was also partially restored under a $\mathrm{N}_{2}$ atmosphere when the medium was supplemented with urea, which is a $\mathrm{CO}_{2}$-generating substrate. When $S$. thermophilus was cultured under $\mathrm{N}_{2}$, a significant reduction of biomass production ( $72 \%$ of dry weight) was observed; this clearly demonstrated that $\mathrm{CO}_{2}$ starvation has a dramatic effect on the energy metabolism of the micro-organism. The use of a 
chemically defined medium under a $\mathrm{N}_{2}$ or an enriched $\mathrm{CO}_{2}$ atmosphere revealed that $\mathrm{CO}_{2}$ depletion determined aspartic acid, arginine and uracil auxotrophy, thus confirming the key role of $\mathrm{PpC}$ and $\mathrm{CpS}$ in S. thermophilus metabolism. It was also concluded that the decarboxylating reactions potentially active in $S$. thermophilus metabolism were not able to efficiently feed the $\mathrm{CO}_{2}$-consuming reactions.

S. thermophilus wild-type was able to grow in CDM broth deprived of arginine, aspartate and uracil under a $\mathrm{N}_{2}$ atmosphere, while it showed a clear auxotrophy for these nutrients when it was cultured on CDM agar under $\mathrm{N}_{2}$. Previous observations (Arioli et al., 2007) have revealed that addition of urea and bicarbonate to CDM broth does not have any effect on the growth of either the parental or the phosphoenolpyruvate-carboxylase-negative mutant strain, indicating that $\mathrm{CO}_{2}$ dissolved in the liquid medium is not present in limiting concentration.

A $\mathrm{CO}_{2}$-concentration-dependent auxotrophy for arginine and uracil has also been reported for some strains of $L$. plantarum (Nicoloff et al., 2005). In L. plantarum, carbamoyl phosphate, the precursor of both pyrimidine and arginine synthesis (Fig. 1), is synthesized by two CpSs, namely CpS-P and CpS-A, encoded by pyrAaAb and $c a r A B$, respectively, whose transcription is regulated by pyrimidine and arginine availability (Nicoloff et al., 2000, 2005). L. plantarum strains showing a high- $\mathrm{CO}_{2}$-requiring auxotroph are able to synthesize sufficient arginine and pyrimidines in $\mathrm{CO}_{2}$-enriched air only. Unlike L. plantarum, $S$. thermophilus has only one CpS, which is encoded by a carB gene (Hols et al., 2005), and this represents a key node in arginine and pyrimidine biosynthesis (Fig. 1). Moreover, in L. plantarum, Lactobacillus paraplantarum and Lactobacillus pentosus, inorganic carbon has been proposed to be the growth-limiting factor in normal air by limiting the synthesis of carbamoyl phosphate (Nicoloff et al., 2005); however, arginine and pyrimidine prototrophs requiring high concentrations of $\mathrm{CO}_{2}$ have not been found in S. thermophilus.

In the available genome of lactic acid bacterial species, phosphoenolpyruvate carboxylase and carbamoylphosphate synthase genes have been identified in Lactobacillus spp. L. delbrueckii subsp. bulgaricus, $L$. acidophilus, L. gasseri, L. helveticus and L. johnsonii, while Lactococcus lactis, L. plantarum, L. brevis and L. salivarius are characterized by the presence of pyruvate carboxylase (E.C. 6.4.1.1) and/or phosphoenolpyruvate carboxykinase (E.C. 4.1.1.49) and carbamoyl-phosphate synthase. Lactobacillus fermentum shows only a putative phosphoenolpyruvate carboxylase, and Lactobacillus casei and Lactobacillus sakei have a putative carbamoyl-phosphate synthase. Other lactic acid bacterial species do not appear to have genes encoding enzymic activities involved in the anaplerotic assimilation of $\mathrm{CO}_{2}$ (Bolotin et al., 2001; Kleerebezem et al., 2003; Pridmore et al., 2004; Chaillou et al., 2005; Van de Guchte et al., 2006; Altermann et al.,
2005; Makarova et al., 2006; Callanan et al., 2008; Claesson et al., 2006; Morita et al., 2008).

The comparative proteomic analysis carried out between cultures of $S$. thermophilus grown under enriched $\mathrm{CO}_{2}$ and those grown in a $\mathrm{N}_{2}$ atmosphere confirmed that $\mathrm{CO}_{2}$ stimulates energy metabolism, as revealed by the upregulation of enzymes involved in glycolysis and homolactic fermentation (Fig. 4). This suggests that cells become metabolically active. Further evidence to support the stimulating effect of $\mathrm{CO}_{2}$ on energy metabolism in $S$. thermophilus was obtained by the demonstration of the distribution of the two HPr isoforms (Fig. 5). The observed prevalence of $\mathrm{HPr}(\mathrm{Ser}-\mathrm{P})$ in cells grown in an enriched $\mathrm{CO}_{2}$ atmosphere again suggested that, under this condition, the culture was in a high level of energy status. In contrast, the high prevalence of $\mathrm{HPr}(\mathrm{His}-\mathrm{P})$ in the proteome of culture grown under a $\mathrm{N}_{2}$ atmosphere seems to reflect that the culture was in a low level of energy status. Considering that, in the two experimental conditions analysed, S. thermophilus was cultured on the same medium, the transition from $\mathrm{HPr}($ Ser-P) to $\operatorname{HPr}($ His- $\mathrm{P})$ seems to reflect the metabolic stress induced by $\mathrm{CO}_{2}$ depletion, i.e. as argued above, depending on arginine, aspartic acid and uracil starvation. The indirect influence of the biosynthetic pathways governed by $\mathrm{PpC}$ and $\mathrm{CpS}$ on the phosphorylation status of HPr was highlighted by analysing the proteome of mutant A19. In this case, $\mathrm{HPr}(\mathrm{His}-\mathrm{P})$ was the dominant phosphorylated form of $\mathrm{HPr}$ for all the experimental conditions applied (Fig. 5). These data are in agreement with the observation that the genetic inactivation of $\mathrm{PpC}$ and $\mathrm{CpS}$ in the mutant A19 caused an auxotrophy for aspartate, arginine and uracil, irrespective of the availability of $\mathrm{CO}_{2}$. Another study (van den Bogaard et al., 2000) has reported the role of the catabolite control protein A (CcpA) on the transcriptional regulation of the lacSZ operon and $l d h$ gene, thereby determining direct control of lactose transport, $\beta$-galactosidase activity and glycolysis. Published data on S. thermophilus show that the regulatory role of CcpA is presumably enhanced by the interaction with HPr(Ser-P) (van den Bogaard et al., 2000). Our results show a direct correlation between the distribution of the HPrphosphorylated isoforms and the measured levels of $\beta$-galactosidase and lactate dehydrogenase activities (Figs 5 and 6), and their relevance in the milk acidification process.

The key role of $\mathrm{PpC}$ and $\mathrm{CpS}$ activity in the $\mathrm{CO}_{2}$ metabolism of $S$. thermophilus was further corroborated when the proteomes of the wild-type and the mutant $\mathrm{A} 19(\Delta p p c ; \Delta c a r B)$ grown under $\mathrm{CO}_{2}$ were compared (Fig. 4). These comparative experiments confirmed previous observations of comparisons between the proteome of the wild-type grown in $\mathrm{CO}_{2}$ versus that of the wild-type grown in $\mathrm{N}_{2}$, i.e. that $\mathrm{CO}_{2}$ depletion produces a modulation of energy metabolism. In conclusion, this study highlights the relevance of $\mathrm{CO}_{2}$ availability for the metabolism of $S$. thermophilus, revealing new insights in the physiology of this micro-organism, and providing new opportunities for industrial applications. 


\section{ACKNOWLEDGEMENTS}

Measurements of the ${ }^{13} \mathrm{C} /{ }^{12} \mathrm{C}$ stable isotope ratio were performed at Unità Operativa Analisi Isotopica degli Alimenti, Dipartimento Laboratorio Analisi e Ricerche Centro Sperimentale Istituto Agrario di San Michele all'Adige, Italy. This research was partially supported by grants from the Italian National Research Council (AG.P04.015 and RSTL 862) to A.S., and by the financial support of Ministero dell'Istruzione, dell'Università e della Ricerca (MIUR) (Prin 2006) to D. M.

\section{REFERENCES}

Altermann, E., Russell, W. M., Azcarate-Peril, M. A., Barrangou, R., Buck, B. L., McAuliffe, O., Souther, N., Dobson, A., Duong, T. \& other authors (2005). Complete genome of the probiotic lactic acid bacterium Lactobacillus acidophilus NCFM. Proc Natl Acad Sci U S A 102, 3906-3912.

Arena, S., D’Ambrosio, C., Renzone, G., Rullo, R., Ledda, L., Vitale, F., Maglione, G., Varcamonti, M., Ferrara, L. \& Scaloni, A. (2006). A study of Streptococcus thermophilus proteome by integrated analytical procedures and differential expression investigations. Proteomics 6, $181-192$.

Arioli, S., Monnet, C., Guglielmetti, S., Parini, C., De Noni, I., Hogenboom, J., Halami, P. M. \& Mora, D. (2007). Aspartate biosynthesis is essential for the growth of Streptococcus thermophilus in milk, and aspartate availability modulates the level of urease activity. Appl Environ Microbiol 73, 5789-5796.

Arsène-Ploetze, F., Kugler, V., Martinussen, J. \& Bringel, F. (2006). Expression of the pyr operon of Lactobacillus plantarum is regulated by inorganic carbon availability through a second regulator, $\mathrm{PyrR}_{2}$, homologous to the pyrimidine-dependent regulator PyrR. J Bacteriol 188, 8607-8616.

Bernhardt, J., Weibezahn, J., Scharf, C. \& Hecker, M. (2003). Bacillus subtilis during feast and famine: visualization of the overall regulation of protein synthesis during glucose starvation by proteome analysis. Genome Res 13, 224-237.

Biswas, l., Gruss, A., Ehrlich, D. \& Maguin, E. (1993). High-efficiency gene inactivation and replacement system for Gram-positive bacteria. J Bacteriol 175, 3628-3635.

Bolotin, A., Wincker, P., Mauger, S., Jaillon, O., Malarme, K., Weissanbach, J., Ehrlich, S. D. \& Sorokin, A. (2001). The complete genome sequence of lactic acid bacterium Lactococcus lactis ssp. lactis IL1403. Genome Res 11, 731-753.

Bolotin, A., Quinquis, B., Renault, P., Sorokin, A., Ehrlich, S. D., Kulakauskas, S., Lapidus, A., Goltsman, E., Mazur, M. \& other authors (2004). Complete sequence and comparative genome analysis of the dairy bacterium Streptococcus thermophilus. Nat Biotechnol 22, 1554-1558.

Bradford, M. M. (1976). A rapid and sensitive method for the quantitation of microgram quantities of protein utilizing the principle of protein-dye binding. Anal Biochem 72, 248-254.

Callanan, M., Kaleta, P., O'Callaghan, J., O'Sullivan, O., Jordan, K., McAuliffe, O., Sangrador-Vegas, A., Slattery, L., Fitzgerald, G. F. \& other authors (2008). Genome sequence of Lactobacillus helveticus: an organism distinguished by selective gene loss and insertion sequence element expansion. J Bacteriol 190, 727-735.

Chaillou, S., Champomier-Vergès, M. C., Cornet, M., Crutz-Le Coq, A. M., Dudez, A. M., Martin, S., Beaufils, S., Darbon-Rongère, E., Bossy, R. \& other authors (2005). The complete genome sequence of the meat-borne lactic acid bacterium Lactobacillus sakei 23K. Nat Biotechnol 23, 1527-1533.
Claesson, M. J., Leahy, S., Canchaya, C., van Pijkeren, J. P., Cerdeño-Tárraga, A. M., Parkhill, J., Flynn, S., O'Sullivan, G. C., Collins, J. K. \& other authors (2006). Multireplicon genome architecture of Lactobacillus salivarius. Proc Natl Acad Sci U S A 103, 6718-6723.

D'Ambrosio, C., Arena, S., Fulcoli, G., Scheinfeld, M. H., Zhou, D., D’Adamio, L. \& Scaloni, A. (2006). Hyperphosphorylation of JNKinteracting protein 1, a protein associated with Alzheimer disease. $\mathrm{Mol}$ Cell Proteomics 5, 97-113.

Eymann, C., Dreisbach, A., Albrecht, D., Bernhardt, J., Becher, D., Gentner, S., Tam le, T., Büttner, K., Buurman, G. \& other authors (2004). A comprehensive proteome map of growing Bacillus subtilis cells. Proteomics 4, 2849-2876.

Garrigues, C., Loubiere, P., Lindley, D. \& Cocaign-Bousquet, M. (1997). Control of the shift from homolactic acid to mixed-acid fermentation in Lactococcus lactis: predominant role of the NADH/ $\mathrm{NAD}^{+}$ratio. J Bacteriol 179, 5282-5287.

Gaspar, P., Neves, A. R., Shearman, C. A., Gasson, M. J., Baptista, A. M., Turner, D. L., Soares, C. M. \& Santos, H. (2007). The lactate dehydrogenases encoded by the $l d h$ and $l d h B$ genes in Lactococcus lactis exibits distinct regulation and catalytic properties comparative modelling to probe the molecular basis. FEBS J 274, 5924-5936.

Giliberti, G., Naclerio, G., Martirani, L., Ricca, E. \& De Felice, M. (2002). Alteration of cell morphology and viability in a recA mutant of Streptococcus thermophilus upon induction of heat shock and nutrient starvation. Gene 295, 1-6.

Gunnewijk, M. G. W. \& Poolman, B. (2000a). Phosphorylation state of HPr determines the level of expression and the extent of phosphorylation of the lactose transport protein of Streptococcus thermophilus. J Biol Chem 275, 34073-34079.

Gunnewijk, M. G. W. \& Poolman, B. (2000b). HPr(His-P)-mediated phosphorylation differently affects counterflow and proton motive force-driven uptake via the lactose transport protein of Streptococcus thermophilus. J Biol Chem 275, 34080-34085.

Hols, P., Hancy, F., Fontaine, L., Grossiord, B., Prozzi, D., LeblondBourget, N., Decaris, B., Bolotin, A., Delorme, C. \& other authors (2005). New insights in the molecular biology and physiology of Streptococcus thermophilus revealed by comparative genomics. FEMS Microbiol Rev 29, 435-463.

Kleerebezem, M., Boekhorst, J., van Kranenburg, R., Molenaar, D., Kuipers, O., Leer, R., Tarchini, R., Peters, S., Sandbrink, H. M. \& other authors (2003). Complete genome sequence of Lactobacillus plantarum WCFS1. Proc Natl Acad Sci U S A 100, 1990-1995.

Link, A. J., Eng, J. K., Schieltz, D. M., Carmack, E., Mize, G. J., Morris, D. R., Garvik, B. M. \& Yates, J. R., III (1999). Direct analysis of protein complexes using mass spectrometry. Nat Biotechnol 17, 676-682.

Louaileche, H., Braquart, P., Saulnier, F., Desmazeud, M. \& Linden, G. (1993). Carbon dioxide effects on the growth and metabolites of morphological variants of Streptococcus thermophilus. J Dairy Sci 76, 3683-3689.

Louaileche, H., Bracquart, P., Guimont, C. \& Linden, G. (1996). Carbon dioxide fixation by cells and cell-free extracts of Streptococcus thermophilus. J Dairy Res 63, 321-325.

MacCoss, M. J., Wu, C. C. \& Yates, J. R., III (2002). Probability based validation of protein identifications using a modified SEQUEST algorithm. Anal Chem 74, 5593-5599.

Makarova, K., Slesarev, A., Wolf, Y., Sorokin, A., Mirkin, B., Koonin, E., Pavolv, A., Pavlova, N., Karamychev, V. \& other authors (2006). Comparative genomics of the lactic acid bacteria. Proc Natl Acad Sci U S A 103, 15611-15616. 
Manachini, P. L., Fortina, M. G., Parini, C. \& Craveri, R. (1985). Bacillus thermoruber sp. nov., nom. rev., a red pigmented thermophilic bacterium. Int J Syst Bacteriol 35, 493-496.

Mastro, R. \& Hall, M. (1999). Protein delipidation and precipitation by tri- $n$-butylphosphate, acetone, and methanol treatment for isoelectric focusing and two-dimensional gel electrophoresis. Anal Biochem 273, 313-315.

Mora, D., Maguin, E., Masiero, M., Ricci, G., Parini, C., Manachini, P. L. \& Daffonchio, D. (2004). Characterization of urease genes cluster of Streptococcus thermophilus. J Appl Microbiol 96, 209-219.

Mora, D., Monnet, C., Parini, C., Guglielmetti, S., Mariani, A., Pintus, P., Molinari, F., Daffonchio, D. \& Manachini, P. L. (2005). Urease biogenesis in Streptococcus thermophilus. Res Microbiol 156, 897-903.

Morita, H., Toh, H., Fukuda, S., Horikawa, H., Oshima, K., Suzuki, T., Murakami, M., Hisamatsu, S., Kato, Y. \& other authors (2008). Comparative genome analysis of Lactobacillus reuteri and Lactobacillus fermentum reveal a genomic island for reuterin and cobolamin production. DNA Res 15, 151-161.

Nicoloff, H., Hubert, J.-C. \& Bringel, F. (2000). In Lactobacillus plantarum, carbamoyl phosphate is synthesized by two carbamoylphosphate synthetases (CPS): carbon dioxide differentiates the arginine-repressed from the pyrimidine-regulated CPS. J Bacteriol 182, 3416-3422.

Nicoloff, H., Elagöz, A., Arsène-Ploetze, F., Kammerer, B., Martinussen, J. \& Bringel, F. (2005). Repression of the pyr operon in Lactobacillus plantarum prevents its ability to grow at low carbon dioxide levels. J Bacteriol 187, 2093-2104.

Palmfeldt, J., Levander, F., Hahn-Hägerdal, B. \& Peter, J. (2004). Acidic proteome of growing and resting Lactococcus lactis metabolizing maltose. Proteomics 4, 3881-3898.

Peng, J., Elias, J. E., Thoreen, C. C., Licklider, L. J. \& Gygi, S. P. (2003). Evaluation of multidimensional chromatography coupled with tandem mass spectrometry (LC/LC-MS/MS) for large-scale protein analysis: the yeast proteome. J Proteome Res 2, 43-50.

Perkins, D. N., Pappin, D. J., Creasy, D. M. \& Cottrell, J. S. (1999). Probability-based protein identification by searching sequence databases using mass spectrometry data. Electrophoresis 20, 35513567.

Pridmore, R. D., Berger, B., Desiere, F., Vilanova, D., Barretto, C., Pittet, A. C., Zwahlen, M. C., Rouvet, M., Altermann, E. \& other authors (2004). The genome sequence of the probiotic intestinal bacterium Lactobacillus johnsonii NCC 533. 2004. Proc Natl Acad Sci U S A 101, 2512-2517.

Reiter, B. \& Oram, J. D. (1962). Nutritional studies on cheese starters. I. Vitamin and amino acid requirements of single strain starters. J Dairy Res 29, 63-77.

Rocco, M., D’Ambrosio, C., Arena, S., Faurobert, M., Scaloni, A. \& Marra, R. (2006). Proteomic analysis of tomato fruits from two ecotypes during ripening. Proteomics 6, 3781-3791.

Salzano, A. M., Arena, S., Tenzone, G., D’Ambrosio, C., Rullo, R., Bruschi, M., Ledda, L., Maglione, G., Candiano, G. \& other authors (2007). A widespread picture of the Streptococcus thermophilus proteome by cell lysate fractionation and gel-based/gel-free approaches. Proteomics 7, 1420-1433.

Sciochetti, S. A., Blakely, G. W. \& Piggot, P. J. (2001). Growth phase variation in cell and nucleoid morphology in a Bacillus subtilis recA mutant. J Bacteriol 183, 2963-2968.

Talamo, F., D’Ambrosio, C., Arena, S., Del Vecchio, P., Ledda, L., Zehender, G., Ferrara, L. \& Scaloni, A. (2003). Proteins from bovine tissues and biological fluids: defining a reference electrophoresis map for liver, kidney, muscle, plasma and red blood cells. Proteomics 3, 440-460.

Van de Guchte, M., Penaud, S., Grimaldi, C., Berbe, V., Bryson, K., Nicolas, P., Robert, C., Oztas, S., Mangenot, S. \& other authors (2006). The complete genome sequence of Lactobacillus bulgaricus reveals extensive and ongoing reductive evolution. Proc Natl Acad Sci U S A 103, 9274-9279.

van den Bogaard, P. T., Kleerebezem, M., Kuipers, O. P. \& de Vos, W. M. (2000). Control of lactose transport, $\beta$-galactosidase activity, and glycolysis by CcpA in Streptococcus thermophilus: evidence for carbon catabolite repression by a non-phosphoenolpyruvate-dependent phosphotransferase system sugar. J Bacteriol 182, 5982-5989.

Wang, H., Weizhu, Y., Coolbear, T., O’Sullivan, D. \& McKay, L. L. (1998). A deficiency in aspartate biosynthesis in Lactococcus lactis subsp. lactis $\mathrm{C} 2$ causes slow milk coagulation. Appl Environ Microbiol 64, 1673-1679.

Wang, H., O’Sullivan, D. J., Baldwin, K. A. \& McKay, L. L. (2000). Cloning, sequencing, and expression of the pyruvate carboxylase gene in Lactococcus lactis subsp. lactis C2. Appl Environ Microbiol 66, 12231227.

Edited by: V. Eijsink 